\title{
Bovine Babesiosis in Turkey: Impact, Current Gaps, and Opportunities for Intervention
}

\author{
Sezayi Ozubek ${ }^{1,2}$, Reginaldo G. Bastos ${ }^{1}$, Heba F. Alzan ${ }^{1,3}{ }^{\oplus}$, Abdullah Inci ${ }^{4,5}$, Munir Aktas ${ }^{2} \mathbb{C}$ \\ and Carlos E. Suarez 1,6,* \\ 1 Department of Veterinary Microbiology and Pathology, Washington State University, Pullman, \\ WA 99164-7040, USA; sezayi.ozubek@wsu.edu (S.O.); reginaldo_bastos@wsu.edu (R.G.B.); \\ heba.alzan@wsu.edu (H.F.A.) \\ 2 Department of Parasitology, Faculty of Veterinary Medicine, University of Firat, 23119 Elazig, Turkey; \\ maktas@firat.edu.tr \\ 3 Parasitology and Animal Diseases Department, National Research Center, Dokki, Giza 12622, Egypt \\ 4 Department of Parasitology, Faculty of Veterinary Medicine, Erciyes University, 38039 Kayseri, Turkey; \\ ainci@erciyes.edu.tr \\ 5 Vectors and Vector-Borne Diseases Implementation and Research Center, Erciyes University, \\ 38039 Kayseri, Turkey \\ 6 Animal Disease Research Unit, USDA Agricultural Research Service, Pullman, WA 99164-6630, USA \\ * Correspondence: carlos.suarez@usda.gov
}

Received: 17 November 2020; Accepted: 9 December 2020; Published: 11 December 2020

\begin{abstract}
Bovine babesiosis is a global tick-borne disease that causes important cattle losses and has potential zoonotic implications. The impact of bovine babesiosis in Turkey remains poorly characterized, but several Babesia spp., including B. bovis, B. bigemina, and B. divergens, among others and competent tick vectors, except Rhipicephalus microplus, have been recently identified in the country. Bovine babesiosis has been reported in all provinces but is more prevalent in central and highly humid areas in low and medium altitude regions of the country housing approximately $70 \%$ of the cattle population. Current control measures include acaricides and babesicidal drugs, but not live vaccines. Despite the perceived relevant impact of bovine babesiosis in Turkey, basic research programs focused on developing in vitro cultures of parasites, point-of-care diagnostic methods, vaccine development, "omics" analysis, and gene manipulation techniques of local Babesia strains are scarce. Additionally, no effective and coordinated control efforts managed by a central animal health authority have been established to date. Development of state-of-the-art research programs in bovine babesiosis to address current gaps in knowledge and implementation of long-term plans to control the disease will surely result in important economic, nutritional, and public health benefits for the country and the region.
\end{abstract}

Keywords: bovine babesiosis; Babesia; bovine; cattle; cattle industry in Turkey

\section{Introduction}

An important chapter on animal infectious diseases began in 1888 with the sudden deaths of thousands of cows in Romania [1]. At the time, Victor Babes associated the animal deaths with an intraerythrocytic organism, which he named as "haematococcus." These organisms were later identified as protozoan parasites, and renamed Babesia to honor its discoverer [2]. A few years later, two researchers in the US, Smith and Kilbourne, found out that Babesia parasites were transmitted by Ixodid ticks, demonstrating for the first time transmission of a parasite by an arthropod vector [3]. Follow up studies have characterized several species of Babesia as tick-transmitted apicomplexan protozoan hemoparasites with veterinary and human importance, and great economic impact worldwide [4]. 
Babesiosis is a disease that affects many vertebrate hosts, from humans to bats, as well as farm animals, such as cattle, horses, and small ruminants, and companion animals [5]. There are more than 100 Babesia species reported so far, with different host specificities [6]. Here, we focus on bovine babesiosis, a disease with a particular large impact on cattle worldwide. In addition to major economic losses derived from death of animals and decreased production of meat and dairy products as a result of bovine babesiosis, there are other important costs associated with tick control, diagnosis, and treatments required to prevent the disease. Despite the importance, there is no reliable specific quantification of the impact of bovine babesiosis at the global scale, but only independent regional assessments performed in individual countries, such as Brazil, Argentina, Australia, among others, and the estimated losses are in the order of hundreds of millions of US dollars per year.

Babesia parasites have a complex lifecycle that includes the development of asexual stages in mammalian hosts and sexual stages inside their definitive tick vectors. Two characteristics that define sensu stricto Babesia parasites are their ability to be transmitted transovarially by tick vectors and exclusively infect red blood cells (RBC) in their vertebrate host. These aspects are particularly important for B. bovis, B. bigemina, and B. divergens, the major causative agents of bovine babesiosis $[6,7]$.

Growth of asexual stages of Babesia parasites inside the vertebrate host RBC causes severe intravascular hemolytic anemia, which is a pathognomonic sign of the acute disease and highly debilitating for the host. Additionally, fever, prostration, abortion, and temporary infertility are also common clinical findings during acute infection. Hemoglobinuria is also usually present at the peak of the hemolytic crisis in B. bigemina or B. divergens infection and in late stages of the disease caused by $B$. bovis. In addition, residues and toxic metabolites released as a result of the infection and RBC destruction can negatively affect host organ systems [6-8]. Moreover, B. bovis has the unique ability to evade the cattle immune system by expressing proteins that facilitate cytoadhesion of infected RBC to capillaries, such as in the brain, causing neurological symptoms and generalized organ failure, a feature that results in increased virulence. Altogether, these pathological mechanisms frequently lead to rapid death of cattle during the acute stage of the disease, especially when affecting adult naïve animals.

Upon infection, the immune system of the host responds differentially, depending on the age of the animals. While young animals, less than seven months old, are frequently able to control severe acute babesiosis and can survive re-exposures to the parasites, older than one-year-old animals often succumb rapidly to infection. Features associated with resistance in young animals include early and strong activation of the innate and adaptive immune effectors. Briefly, the parasite expresses molecules able to bind pathogen associated molecular patterns (PAMPs) receptors expressed on the surface of dendritic cells (DC), macrophages, neutrophils, and monocytes, especially TLR9 $[9,10]$, and an immune response is initiated. Cytokines, such as IL- $1 \beta$, TNF- $\alpha$, and IL-12, and nitric oxide (NO) are released from monocytes and neutrophils, and chemokines attract immature DC to the site of infection, especially at the spleen. These stimulate natural killer cells (NKs) that release early IFN $\gamma$. The mature DC migrating to the spleen presents Babesia antigens to naive T cells. Spleen macrophages are activated by IFN $\gamma$, phagocytize infected $\mathrm{RBC}$, and kill the parasites by releasing reactive nitrogen and oxygen intermediates. In turn, cytokines, such as $1 \mathrm{~L}-1 \beta$, IL-12, and TNF- $\alpha$, released from activated macrophages inhibit the growth of $B$. bovis. Activated $\mathrm{CD} 4^{+} \mathrm{T}$ cells and specific B-cell producing antibodies are also important in maintaining immunity and overcoming the infection [11-14]. Despite mounting protective adaptive immune responses, animals that survive acute babesiosis develop persistent infection, which allows transmission and perpetuation of Babesia parasites in endemic areas. These areas usually have elevated prevalence of bovine babesiosis but low numbers of clinical cases due to the establishment of endemic stability, a condition of herd immunity that develops when more than $75 \%$ of the animals have acquired protective immunity by exposure to the parasite before one year of age, when animals are less susceptible to the parasites. A highly unstable state may occur, in contrast, when less than $30 \%$ of the herd is naïve for the disease [15-17].

B. bovis and B. bigemina, which are transmitted by Rhipicephalus ticks, are the most important causative agents of bovine babesiosis in tropical and subtropical regions worldwide. In addition, 
B. divergens is another important Babesia species that is transmitted by Ixodes ticks and affects cattle in Europe and North Africa. Apart from its impact on bovines, B. divergens is especially important as a zoonotic pathogen implicated in human babesiosis in Europe [6-8,18]. Acute bovine babesiosis caused by B. bovis is often severe due to cytoadhesion of infected RBC in the lung, kidney, and brain capillaries, which leads to hypotension, respiratory stress syndrome, neurological symptoms, and death $[8,19]$. In contrast, $B$. bigemina induces massive hemolytic anemia without causing the symptoms associated with cytoadhesion $[4,6,18]$. Also of importance as causative agents of bovine babesiosis are B. ovata, B. major, B. occultans, and additional unclassified Babesia that are characterized by their low pathogenicity in cattle compared to B. bovis, B. bigemina, and B. divergens [8,20-24].

Numerous cases of bovine babesiosis involving most of these mentioned Babesia species have been reported throughout the years (from 1955 to 2020) in Turkey. Despite the overall economic importance of bovine babesiosis worldwide, only relatively few studies have addressed the impact of the disease on the cattle industry in this country, and updates on this important subject have also been overlooked in recent years. Therefore, the focus of this study is on compiling relevant studies to improve our understanding of the effect of bovine babesiosis on the Turkish cattle industry, with the aim of assessing the current status of the disease and identifying research and intervention gaps that can contribute to improved control of this disease. Here we cover not only the major causative agents $B$. bovis, $B$. bigemina, and B. divergens, but also less virulent species recently identified in Turkey, such as B. major and B. occultans, among others. In addition, we seek to stimulate basic and applied research on this field that is currently neglected with the expectation that this will result in substantial benefits on food production, animal health, economic growth, and human well-being in Turkey and surrounding countries.

\section{An Overview of the Cattle Industry in Turkey}

Turkey is a transcontinental country located in the Northern hemisphere with a territory spanning the Anatolian peninsula in Western Asia and a small portion on the Balkan Peninsula in Southeastern Europe. Geographic coordinates of the country lie at latitude 39 and longitude 35. It is a peninsula with a strategic position as a land connection between Europe and Asia. Considering its location, the country has been also regarded as a natural bridge for transcontinental transmission of tick species and tick-borne diseases (TBD) [25]. Turkey covers an area of $783,582 \mathrm{~km}^{2}$ with a population of 82 million people. The country's economy is based on modern industry, tourism, and trade, and is also heavily supported by the agricultural sector. Therefore, the presence of emerging tick populations and TBD can pose a serious risk to the cattle industry that may impact the overall economy of Turkey and neighboring countries $[25,26]$.

Although the importance of cattle has been different in every society throughout the history of humanity, these animals have always had significant importance in several cultures and religions, and still remain an important economic asset in Turkey and worldwide. There are approximately 66 million farm animals in Turkey, and 27\% of which (18 million) are cattle. In Turkey, milk production consisted of $90.5 \%$ cattle, $6.6 \%$ sheep, and $2.5 \%$ goat. As for meat production, $89.5 \%$ of the total meat produced in Turkey comes from cattle. According to a report from 2018, approximately 1.5 million live animals are imported to Turkey [27]. Some of these animals come from countries that are endemic for cattle ticks, bovine babesiosis, and other cattle TBD, such as Brazil, from where Turkey obtains $42 \%$ of its total imported animals $[27,28]$. Considering that cattle are a very important source of protein, especially meat and milk production, the cattle industry is a significant sector to secure food supply and sustain the economy in Turkey [27]. Assuring constant supply of cattle milk and meat requires keeping high animal sanitary standards and rational strategies for industry development. In addition, particular attention should be placed in controlling diseases that limit cattle production and may compromise public health. This should be extended to the potential introduction of additional animal health risk factors, such as foreign pathogenic organisms. Taking into consideration the social and economic importance of cattle in Turkey, we argue that the development of a national intensive research 
program on TBD, specifically in bovine babesiosis, and the implementation of informed animal health policies of disease control based on the state-of-the-art knowledge should be considered issues of crucial importance for the country.

\section{Economic Impact of Bovine Babesiosis on the Cattle Industry in Turkey}

It is estimated that more than 500 million cattle are at risk of babesiosis worldwide; therefore, this disease poses a major threat to animal health and human livelihood in areas where Babesia parasites and competent tick vectors are present [4]. As an attempt to contain such threat, a radical tick control campaign was launched in the US at the beginning of the 20th century, lasting 40 years and demanding the use of millions of taxpayer's dollars. With this effective, but costly campaign, bovine babesiosis was eradicated in the US, and consequently approximately $\$ 3$ billion US dollars annually were saved for the livestock industry $[6,29,30]$. Unfortunately, the success of this approach was not reproduced in other countries that also attempted similar tick eradication [31], and given a current scenario of increased acaricide resistance in ticks and climate change, among other factors, it is unlikely that this achievement can be duplicated elsewhere [30-32].

Annual economic losses due to bovine babesiosis and anaplasmosis in the world range from $\$ 16.9$ million US dollars in Australia, \$21.6 million US dollars in South Africa, and \$57.2 million US dollars in China [8]. These losses are not only due to animal mortality, but also abortion, decrease in meat and milk production, and disease control costs (e.g., spraying, vaccination, disease treatments, professional veterinary support, and others). In addition, disease-related deaths are frequently observed in naïve cattle imported to regions with enzootic stability for bovine babesiosis [6,8,33], a factor that causes additional economic losses and complicates the attempts to carry out genetic improvement of herds. In this way, preventing clinical cases of bovine babesiosis by strategies based on maintaining enzootic stability may also interfere with the efforts to improve productivity, such as increased weight and milk production, heavily affecting the meat and dairy industries, respectively, which increases production costs $[6,8,17]$.

Turkey's geographic location and climatic conditions, in addition to the country's animal management systems, encourage the occurrence of ticks and TBD $[25,26]$. The emergence of tick populations and TBD have increased around the globe in the recent years, including in Turkey [25]. Estimation of the amount of TBD drugs sale per year during the disease seasons indirectly shows the importance of these diseases on animal health and in the economy of Turkey [26]. The economic impact of topical theileriosis caused by Theileria annulata, a tick-borne parasite similar to Babesia sp., was estimated at a total annual loss of approximately 600,000 US dollars in Turkey [34]. However, despite being considered as a costly burden, the actual economic impact of bovine babesiosis on the cattle industry in Turkey remains largely unknown. Therefore, a well-designed national surveillance study to evaluate the real impact of the disease on the cattle industry in the country is urgently needed.

\section{Competent Tick Vectors for Babesia Parasites Identified in Turkey}

Tick vectors are essential components for the completion of the lifecycle of Babesia parasites. Thus, competent ticks must provide the environment required for sexual reproduction, which occurs in their midgut, and for invasion of tick eggs by the kinete stage of parasites that circulates in the tick hemolymph, an event that ultimately guarantees transovarial transmission of Babesia. A large number of Ixodid tick species are listed as competent Babesia vectors in the literature [5]. Of these, 22 were confirmed vectors for 18 different Babesia species that infect livestock, companion animals, and humans [5]. Identification of pathogen DNA in adult ticks cannot be accepted alone as evidence of vector competence, and more detailed studies on tick-Babesia interactions are needed to establish the tick competence. Additionally, the presence of Babesia DNA in the salivary glands, eggs, and unfed larvae, though more convincing, also requires confirmation as a measure of tick competence [5]. B. bovis and B. bigemina are transmitted by R. annulatus, R. microplus, and R. geigyi ticks found in tropical and temperate regions of the world. B. bigemina can also be transmitted by $R$. decoloratus and R. evertsi, 
making it the most common Babesia species infecting cattle in Africa [8,35]. B. divergens are transmitted mainly by I. ricinus, which develops only in moisture-saturated microhabitats [19]. B. occultans, B. major, B. orientalis, and B. ovata are transmitted by Hyalomma rufipes, Haemaphysalis punctata, R. haemaphysaloides, and Hae. longicornis, respectively [5]. A summary of known competent tick vectors implicated in bovine babesiosis is shown in Table 1, where we highlight the species present in Turkey.

Table 1. Babesia spp. currently identified in cattle with proven vectors and geographical distribution.

\begin{tabular}{|c|c|c|c|}
\hline Species & Geographical Distribution & Vectors/ITS/TOT & References \\
\hline B. bovis * & tropics, subtropics & $\begin{array}{c}\text { R. annulatus } \Psi / \mathrm{L} /+ \\
\text { R. australis/L/+ } \\
\text { R. microplus/L/+ }\end{array}$ & [36-38] \\
\hline B. bigemina * & tropics, subtropics & $\begin{array}{l}\text { R. annulatus } \Psi / \mathrm{A} /+ \\
\text { R. australis/N, A/+ } \\
\text { R. decoloratus/N, A/+ } \\
\text { R. microplus/N, A/+ } \\
\text { R. evertsi/N/- } \\
\text { R. bursa } \Psi / \mathrm{N}, \mathrm{A} / \pm\end{array}$ & {$[36,39-41]$} \\
\hline B. divergens * & Europe, North Africa, Russia & Ixodes ricinus $\Psi / \mathrm{L}, \mathrm{N}, \mathrm{A} /+$ & [42] \\
\hline B. major* & Europe, North Africa, temperate Asia & Hae. punctata $\Psi / \mathrm{L}, \mathrm{N}, \mathrm{A} /+$ & [40] \\
\hline B. occultans * & Africa (Southern Europe, Russia) & Hy. rufipes $\Psi / \mathrm{A} /+$ & [43] \\
\hline B. orientalis & East Asia & R. haemaphysaloides/A/+ & [44] \\
\hline B. ovata & East Asia & Hae. longicornis/L, N, A/+ & [45] \\
\hline
\end{tabular}

Asterisks $\left(^{*}\right)$ and Psi symbols ( $\left.\Psi\right)$ indicate the Babesia species and the tick species reported in Turkey respectively. Abbreviations: ITS, Infective Tick Stage; TOT, Transovarial transmission; L, larvae; N, nymph; A, adult.

To date, R. annulatus, R. bursa, R. turanicus, R. sanguineus, Hy. anatolicum, Hy. dromedari, Hy. detritum, Hy. excavatum, Hy. marginatum, Hy. rufipes, Hy. aegyptium, Dermacentor marginatus, D. niveus, I. ricinus, and Hae. parva ticks have been reported infesting cattle in Turkey [25,46], and some of them were associated with transmission of cattle Babesia parasites (Table 1). In a study using ticks collected from cattle in the Black Sea region, Babesia parasites were reported in Hy. marginatum, Hy. Excavatum, and $R$. turanicus at the rates of 3.5\%, 2.3\%, and 6.6\%, respectively [47]. Babesia sp. Kayseri 1, a novel parasite isolate, was identified in Hy. marginatum feeding on cattle in the Kayseri province located in Central Anatolia [48]. B. bigemina was also reported in unfed larvae from R. annulatus in this same province [48]. In another study in the same region, B. bigemina was found in tick populations of R. annulatus, R. turanicus, Hy. marginatum, and Hy. Anatolicum, whereas B. bovis positive samples were detected in Hy. marginatum ticks [49]. B. occultans was reported in Hy. marginatum and R. turanicus, as well as in their eggs, and thus, these findings suggest that this later tick can also be a competent vector for B. occultans [50]. In another study, B. occultans was identified in questing Hy. marginatum [51]; however, despite the findings, effective transmission of Babesia by these ticks remains to be demonstrated in Turkey.

Collectively, currently available data indicate the presence and expansion of tick populations in Turkey. In addition, most of these tick species have been shown to be competent in transmitting Babesia parasites implicated in bovine babesiosis. Considering the current environmental changes and the importance of the cattle industry in Turkey, epidemiological and entomological studies focused on ticks associated with Babesia transmission are urgently needed in the country. Given the absolute dependence of ticks for parasite survival, identifying all competent vectors for Babesia species circulating in the country and a more complete understanding of the dynamics of the Babesia-tick interactions will be essential to achieve improved control of bovine babesiosis in Turkey. 


\section{Current Control Methods}

Live, attenuated, blood based Babesia vaccines, combined with babesicidal drugs and strategies to control tick vectors, are commonly used to prevent and treat bovine babesiosis worldwide, especially in endemic areas. Here we present a brief description of these methods and their applications and importance for the control of bovine babesiosis in Turkey.

\subsection{Anti-Babesia Vaccines}

Live vaccines based on attenuated parasites are widely used to control bovine babesiosis in many countries, such as Australia, Israel, and Argentina $[8,10,17]$. B. bovis attenuated vaccine strains are produced by quick serial passages of infected blood in splenectomized calves (ranging from 23-30 animals) [52]. In contrast, $B$. bigemina vaccine strains are produced by slow serial passages ( 3 to 16-week intervals) in intact spleen calves [53]. Attempts were also made to produce a live vaccine for B. divergens in splenectomized calves or intact gerbils. However, treatment with babesicidal drugs was needed to prevent clinical manifestations after vaccination [18], and due to its poor efficacy, this anti- $B$. divergens live vaccine is no longer in use [18]. The mechanisms involved in the process of attenuation of Babesia parasites during passages in calves still remain unknown, but recent genomic and transcriptomic comparative analyses among parental virulent and their derived attenuated vaccine strains have shed some light on the presence of differences in the patterns of expression of a limited number of genes [54]. For instance, expression of the spherical body protein 2t11 (SBP211t) was found upregulated in attenuated vaccine strains of B. bovis [55], suggesting that comparing the levels of expression of this gene among strains could be correlated with virulence. Hence, it would be of relevance to compare the pattern of expression of SBP2t11 among local parasite strains isolated in Turkey in order to select parasites that could be candidates for the development of live vaccines.

Despite their relative efficacy, current live vaccines have several limitations, and their use for the control of bovine babesiosis is somehow considered a double-edged sword. On one side, live vaccines remain the most effective way of controlling acute bovine babesiosis, especially considering that there are no safer alternative subunit vaccines available against the disease. Additionally, a study performed in Argentina suggested that the systematic application of live Babesia vaccines in calves might render a benefit-cost ratio between 4.6 and 9.0 [56]. Ojeda et al. 2010 [57] also reported high levels of protection conferred by the vaccine $(93 \%)$ and demonstrated a ratio of ill/healthy (vaccinated:non-vaccinated) animals of 1:6.5. On the other side of the sword, production of live vaccines is expensive and laborious, cold chain is needed, and contamination with infectious agents and reversion to virulence of vaccine strains remain a possibility. In addition, live vaccines may also lead to transmission of the vaccine strains by ticks, which can contribute to the generation of antigenic diversity among field strains and affect endemic stability. To prevent these problems, live vaccines lacking genes required for sexual reproduction of the parasite using transfection or gene editing technologies can be alternatively developed [58]. Other options available to overcome the various disadvantages of live vaccines are to develop formulations containing killed parasites, soluble parasite antigens (SPAs), and recombinant protective parasite antigens [59]. SPAs are released into peripheral blood during Babesia infection, and promising results in B. canis and B. rodhaini studies suggest that these antigens are potential candidates for developing similar vaccines against other Babesia species [60]. Thus, SPAs prepared from supernatants of in vitro cultures have shown promising results against B. bigemina [61], B. canis [62], $B$. divergens [63], and B. orientalis [64]. However, on the downside, it was found that vaccines based on B. bovis SPAs were more effective in protecting against challenge with homologous than heterologous strains, raising concerns about their use as universal vaccines.

Although many studies have been conducted to develop subunit vaccines against babesiosis based on recombinant proteins, a commercial-grade product has still not been obtained so far. The use of eukaryotic instead of prokaryotic expression systems mixed with new-generation adjuvants has been recommended in order to increase vaccine efficacy [59]. Recombinant proteins can also be used in the development of transmission-blocking vaccines (TBV), based on parasite sexual stage 
proteins that are usually exclusively expressed in ticks $[58,65,66]$. Testing of candidate antigens for TBV against Plasmodium [67] have suggested the notion that such vaccines may also be efficient against Babesia [59]. Several previously characterized B. bovis sexual and tick-stage antigens, such as HAP2 [66], CCp1-3 [65], and 6 Cys [58,68], are also being currently considered as candidates for TBV. In addition, recently characterized $B$. bigemina sexual-stage antigens are also considered as possible candidates for the development of TBV $[69,70]$. A possible future effective vaccination strategy would be a combination of a TBV, which can block the development of sexual stage parasites in ticks to prevent parasite transmission in endemic regions, with a blood-stage live subunit vaccine to prevent acute babesiosis. Hence, this combination of blood and tick-stage antigens can provide effective protection while, at the same time, diminishing the load of Babesia circulating in tick vectors in endemic areas. Yet, these vaccines will still require the pending definition of protective and well-conserved blood and tick stage antigens. An important body of work has been also developed in the search of blood stage vaccine candidate antigens, using several approaches. Thus, the B. bovis RAP-1 [71], RRA [4], MSA-2 [72], TRAPs [73], and AMA-1 [74,75] proteins, among others, are currently being investigated as a component of subunit vaccines. It would be important to determine the degree of conservation of such candidate antigens in B. bovis strains isolated in Turkey as well as the presence of equivalent homologous proteins expressed by other cattle Babesia parasites common in this country.

Live vaccines are not currently under production, and therefore, not being utilized in Turkey to prevent bovine babesiosis, and acaricides aimed at controlling ticks is the only method for the disease prevention in use in the country, as described in detail below. However, it needs to be considered that a Babesia-control strategy based solely on targeting vector control appears unrealistic due to multiple factors that include the constant emergence of acaricide resistant tick strains, the multiplicity of competent vectors for these parasites, global climate change that favors the geographic expansion of ticks, and the negative impact that acaricides may have on the environment, among others.

\subsection{Anti-Tick Control Strategies}

Acaricides have been applied for centuries to reduce the harmful effects of ticks and TBD on their vertebrate hosts. Although they have shown efficacy in controlling ticks, acaricides have numerous disadvantages, such as contamination of animal products and the environment. As a control strategy against babesiosis, acaricides are used to decrease or prevent tick infestation of susceptible hosts. However, with the gradual global emergence of acaricide-resistant ticks, the need for the development of new effective drugs and anti-tick vaccines are needed worldwide [17,76]. Yet, despite the implications derived from the emergence of acaricide resistant tick populations, such reports remain unavailable in Turkey. Currently, formamidines, synthetic pyrethroids, phenyl pirazoles, and macrocyclic lactones are used for tick control in the country [25]. The target site for organophosphates and carbamates are acetylcholinesterases that break down the neurotransmitter acetylcholine, while the targets for pyrethroids are voltage-gated $\mathrm{Na}^{+}$channel regulatory proteins of the nerve membrane [77]. Alternatively, the use of anti-tick vaccines surge as an economical and environmentally sustainable approach. Two commercial anti-tick vaccines, TickGARD and Gavac, also known as Bovimune Ixovac in Mexico (http://www.lapisa.com), against R. microplus have been used around the world [78]. While apparently Gavac continues to be commercialized in Cuba (Heber Biotec S.A., Havana, Cuba), and more recently Bovimune Ixovac in Mexico (Lapisa, S.A. de C.V., La Piedad, Mexico), TickGARD is no longer commercially available [79]. These subunit anti-tick vaccines are based on the concealed tick midgut glycoprotein antigen Bm86, which has shown efficacy in reducing the number of engorged female ticks, their weight and fertility capacity, and also in decreasing larval infestation in subsequent tick generations. Cost-effectiveness analysis showed a $60 \%$ reduction in the number of acaricide treatments, together with the control of tick infestations and transmission of babesiosis, which resulted in savings of US \$23.4 animal/year [80]. A comprehensive vaccination program in Venezuela reported that the Gavac ${ }^{\mathrm{TM}}$ vaccine reduced the use of chemical acaricides by $83.7 \%$. The vaccine program was also reported to reduce $81.5 \%$ of the estimated cost of conventional chemical tick control procedures [81]. 
Despite their initially demonstrated efficacy, Bm86 vaccines did not show consistent protection when applied in diverse geographic locations around the world [82]. This lack of effectiveness may be in part due to antigenic polymorphisms, patterns of expression in the ticks, or intrinsic characteristics of the Bm86 antigen, such as conformation and post-translational modifications. It is important to highlight that none of these Bm86-based anti-tick vaccines are used or commercialized in Turkey. Additional tick antigens, such as Bm91 and Bm95 (alternative polymorphic versions of Bm86 isolated from an Argentinian R. microplus strain resistant to vaccination with Bm86), among others, have been characterized and also considered for vaccines $[76,83]$. Whether Bm86 vaccines or other vaccine based on Bm86 alternative antigens may contribute to tick control in Turkey remains unknown since none of them has been tested in a field trial and are unavailable for use in the country. Tick genome analysis, together with the integration of transcriptomics, proteomics, and metabolomics datasets will surely facilitate the identification of effective protective antigens. Recently, "omics" technologies have shown to be effective approaches for the characterization of tick-host-pathogen molecular interactions, and the potential for vaccine development has emerged. These vaccines should be designed considering tick vector species and susceptible hosts [84]. Studies have shown that the "vaccinomics" approach to select protective antigens (Silk and Subolesin) is valid, and it has been shown that vaccines based on tick proteins involved in vector-pathogen interactions can be used for controlling tick infestation and pathogen infection $[85,86]$.

\subsection{Babesia Drug-Control Strategies}

Imidocarb dipropionate and diminazen acetate are the most common drugs used in the treatment of babesiosis in cattle and other animals. Despite their efficacy in controlling acute disease in some cases, these drugs are expensive and leave residual metabolites in milk and meat. Continuous or inappropriate use of these drugs can also lead to parasite resistance [87]. As a result of all these adversities, research efforts have been focused on developing new alternative, effective, and affordable drugs with low toxicity for the control of bovine babesiosis. It has been reported that strategies based on the combination of chemotherapeutics are significantly more effective at eliminating parasites compared to single-drug treatment, which also has the potential to induce greater parasite drug resistance [88]. In addition, combined chemotherapy decreases toxic side effects by reducing the dosages of individual medications (not reported for imidocarb and diminazen) [89]. In recent years, many drugs, such as nimbolide, gedunin, enoxacin, luteolin, pyronaridine tetraphosphate, nitidine chloride, camptothecin, tulathromycin, trifluralin, 17-DMAG, thymoquinone, clofazimine, carfilzomib, and doxorubicin hydrochloride, have been investigated in vitro against Babesia parasites [90-99]. Despite promising results, none of these drugs are used in the field as commercially available treatments for bovine babesiosis.

Another important consideration that limits the use of chemotherapeutics, besides their elevated cost and the possible development of drug resistance, is their potential to interfere with the development of herd anti-Babesia immunity in endemic areas. Thus, even when this approach may be effective in the treatment of acute bovine babesiosis, the use of chemotherapeutics is not considered an ideal control method. Noteworthy, the only chemotherapeutic drug licensed for use in Turkey to treat bovine babesiosis is imidocarb dipropionate [100] complemented at times with supportive treatments, such as iron preparations, dextrose, B vitamins, and fluid replacement, which are especially important in acute severe cases.

Considering the current progresses and drawbacks associated with the available anti-Babesia vaccines, babesicidal drugs, and tick control measures, we suggest the design and implementation of pro-active national and international collaborative programs to assess the current situation, identify current gaps, and design improved control strategies. As an example, identification, characterization and integration of local strain of Babesia parasites that cause bovine babesiosis in Turkey in the development of novel control measures for the disease can greatly increment the preparedness of the country to adequately manage this important animal health concern. 


\section{Diagnosis of Bovine Babesiosis}

Although clinical symptoms, season, and tick infestation may be suggestive of the occurrence of bovine babesiosis, confirmatory diagnosis using different techniques needs also to be applied. In addition, the use of diagnostic tests has an important value for epidemiological studies and to evaluate the need for intervention measures based on the status of the herds, especially to determine whether there is a situation of enzootic stability or instability. Direct identification of Babesia infected-RBC using microscopy has been used traditionally to diagnose bovine babesiosis and is still used today as a practical and inexpensive tool. In the acute period of the disease, the number of parasites in RBC usually increases to a level where they can be readily detected microscopically. This is the case especially for Babesia parasites that typically cause high parasitemia, such as B. bigemina. Yet, this is not usually the case of acute $B$. bovis infection where infected RBC are hard to find in stained blood films, since they can sequester in large numbers in blood capillaries, in an apparent effort to avoid passing through lymphoid organs, such as the spleen. Additionally, analysis of stained blood films in sub-clinically infected large herds, especially in epidemiological studies, is cumbersome, poorly sensitive, and of limited value. Therefore, more sensitive methods, such as serological assays and molecular tests, should be used. While serological assays are designed to detect immune responses (antibodies) produced by exposed hosts, molecular tests, such as standard PCR, nested-PCR, real-time quantitative PCR, reverse line blot (RLB), and loop-mediated isothermal amplification (LAMP), are aimed at revealing the presence of parasite DNA in the vertebrate host $[18,87]$. Thus, there is a short window of time at the onset of acute infection (approximately 12-15 days post-infection) when antibodies may not be detected by current serological methods. In turn, this is the stage marked by rapid and unchecked expansion of the parasite in the host, and then, the infection can be promptly detected by molecular methods. However, one possible drawback of PCR methods is the occurrence of false positives due to the persistence of DNA for a short time after effective treatment [101]. Conversely, persistently infected animals may have non-detectable levels of parasite DNA, but detectable levels of circulating anti-Babesia antibodies. Therefore, a serological test must be designed based on species-specific antigens that are able to elicit long-term responses and high antibody titers. Yet, serological tests may often have some disadvantages, such as the possible occurrence of poor immune responses in target animals resulting in undetectable levels of antibodies, limited sensitivity of the tests, and cross reactions between parasite species that may turn the tests non-specific. Molecular methods to directly detect the parasite in the field may overcome some of these downsides. RLB has been a preferred method in recent years for the detection of TBD, such as theileriosis, babesiosis, and anaplasmosis, due to its high sensitivity and ability to detect multiple species simultaneously [87]. The use of this technique has allowed the identification of new species and genotypes of Babesia parasites worldwide, including Turkey $[102,103]$.

Classic microscopic, serological, and molecular methods have been used for the diagnosis of bovine babesiosis in Turkey $[25,26]$. Although a set of reliable Babesia-diagnostic tests is available nowadays, most of these techniques have disadvantages, such as requiring training and expertise, which makes them difficult to use in field conditions [87]. Alternative rapid and simple point of care strip tests could be developed for this purpose, which requires no previous training for their use, and utilized for the diagnosis of babesiosis, as previously described [104]. Although many studies on strip methods based on immunochromatography or lateral flow test have been done recently $[105,106]$, there is no commercial product available to date worldwide and in Turkey as well, and developing such tests in the future may become important to aid at campaigns designed for the control of bovine babesiosis in this country.

\section{Current Status of Bovine Babesiosis in Turkey}

Bovine babesiosis has been currently reported in all geographic regions of Turkey. Detection of parasites in the country first began with microscopic description of B. bigemina in 1890 [107]. After that, serological studies based on Indirect Fluorescent Antibody Technique (IFAT) revealed exposure to B. bovis, B. bigemina, and B. divergens parasites in different regions of Turkey [108-110]. 
Molecular techniques, such as PCR and RLB, have been recently used to investigate the presence of bovine babesiosis in the country $[100,111,112]$. Combined serology and molecular results have shown that bovine babesiosis caused by B. bovis, B. bigemina, B. divergens, B. major, and B. occultans is widespread in several areas of Turkey (Table 2 and Figure 1). Microscopic, serological and molecular methods have shown a wide range prevalence of Babesia in cattle in Turkey. The wide range of variation in prevalence described in Table 2 may be due to the use of distinct survey methods with different sensitivities and specificities and/or to real differences among the sets analyzed. These observations underscore the fact that no standardized and systematic survey on bovine babesiosis was so far performed in the country. As a result, the prevalence of bovine babesiosis in Turkey remains unknown. B. bovis was first reported by Mimioglu et al. 1969 [113] in cattle in the Black Sea region. Subsequent studies showed that the incidence of B. bovis by microscopic analysis ranged between $0.2-9 \%$ in the Central Anatolian Region, $3.7-29.5 \%$ in the Black Sea Region, $1.5 \%$ in the South East Anatolia Region and 34.8\% in the Marmara Region. Serological studies focused on B. bovis have demonstrated evidence for parasite exposure in herds in all Turkish regions with incidence ranging from 0.6 to $59 \%$. A serological study conducted in 3,773 cattle from all provinces revealed a B. bovis prevalence of $34 \%$ [110]. In addition, direct assays for B. bovis have revealed that the prevalence for B. bovis ranged between $0.4-12.7 \%$ in Turkey (Table 2 and Figure 1).

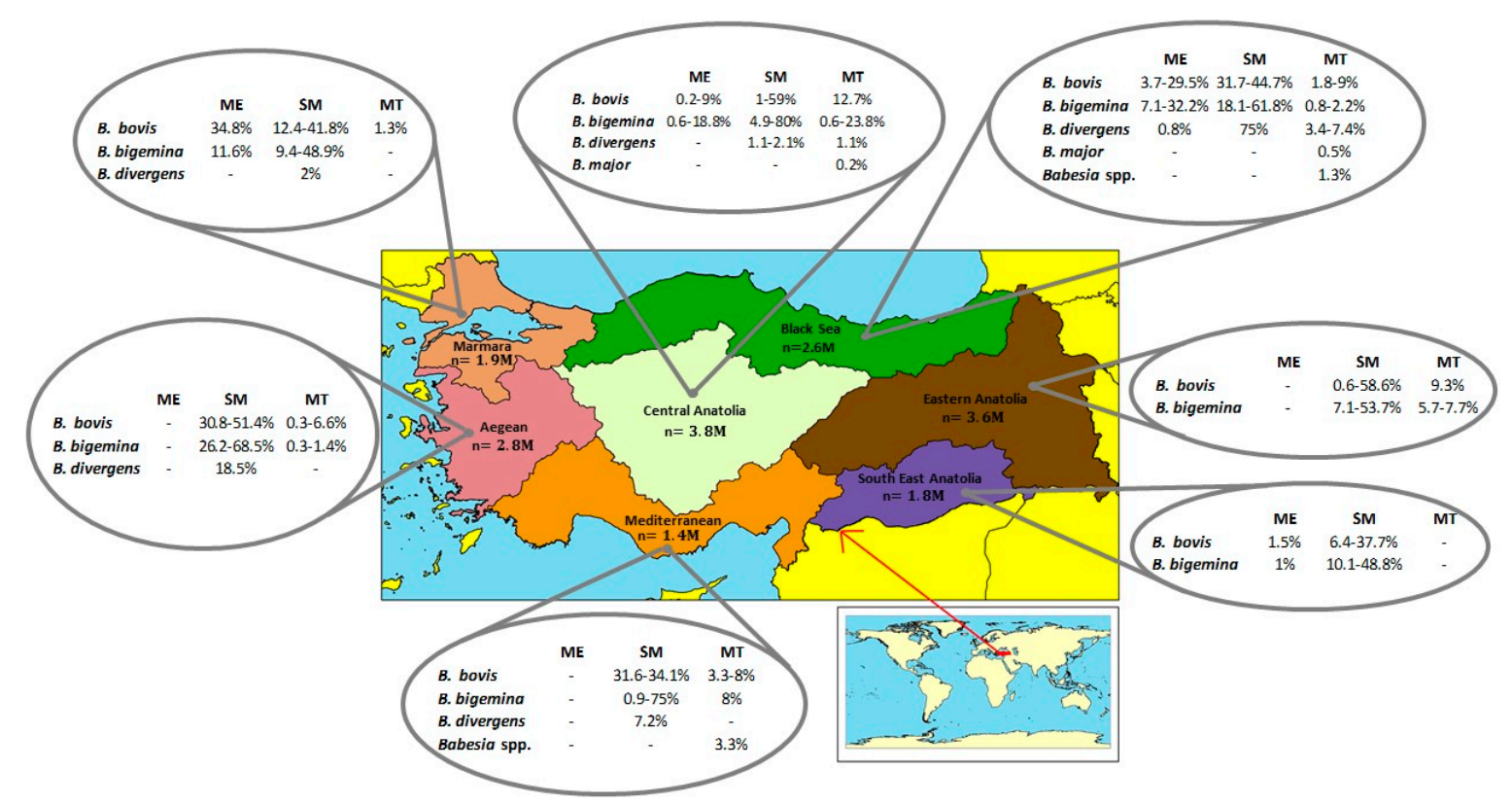

Figure 1. Prevalence rates of bovine Babesia species in the seven geographical regions of Turkey according to the microscopic examination (ME), serologic methods (SM), molecular techniques (MT).

Microscopy analysis revealed that the incidence of B. bigemina is $0.6-18.8 \%$ in the Central Anatolian Region, $7.1-32.2 \%$ in the Black Sea Region, $1 \%$ in the South East Anatolia Region, and $11.6 \%$ in the Marmara Region. Similar to B. bovis, serological assays for B. bigemina have shown evidence of parasite exposure $(0.9-80 \%)$ in all regions in Turkey. A study conducted across the country showed seroprevalence for B. bigemina to be $26.3 \%$. The prevalence of B. bigemina in molecular studies has been reported at the rate of $0.6-18.2 \%$ (Table 2 and Figure 1 ).

There have been only a few studies performed so far in cattle designed to examine the prevalence of B. divergens in Turkey, and the parasite was detected microscopically in only one particular study [100]. Serological studies in cattle reported $75 \%$ positivity in the Black Sea region, $7.2 \%$ in the Mediterranean region, $18.5 \%$ in the Aegean region, and $9.4-48.9 \%$ in the Marmara region. B. divergens prevalence based on molecular techniques was reported as $3.4-7.4 \%$ and $1.1 \%$ in the Black Sea and Central Anatolian Regions, respectively (Table 2 and Figure 1). 
Table 2. Description of Babesia spp. present in cattle in Turkey, diagnostic method used in parasite identification, parasite prevalence, and cited references.

\begin{tabular}{|c|c|c|c|}
\hline Species & Method & Prevelance (\%) & Reference \\
\hline \multirow{3}{*}{ B. bovis } & $\mathrm{ME}$ & $0.2-34.8$ & $\begin{array}{l}\text { Göksu } 1959 \text { [120]; Göksu } 1970 \text { [121]; Cakmak } 1987 \text { [108]; } \\
\text { Tuzer } 1981 \text { [122]; Ozer et al., } 1993 \text { [123]; Acıc1 } 1995 \text { [124]; } \\
\text { Inci et al., } 2002 \text { [125]; Inci 1992 [126] }\end{array}$ \\
\hline & $\mathrm{SM}$ & $0.6-59$ & $\begin{array}{c}\text { Cakmak } 1987 \text { [108]; Sayın et al., } 1989 \text { [127]; } \\
\text { Dincer et al., 1991; Inci 1992 [126]; Eren 1993 [128]; } \\
\text { Sayın et al., } 1996 \text { [109]; Ica } 2004 \text { [129]; } \\
\text { Vatansever et al., } 2003 \text { [114]; Aktas et al., 2001 [130]; } \\
\text { Inci et al. 2002 [125]; Sayın et al. 1996 [109]; } \\
\text { Kalkan et al., } 2010 \text { [131]; Oncel et al., } 2010 \text { [110] }\end{array}$ \\
\hline & MT & $0.4-12.7$ & $\begin{array}{c}\text { Tanyüksel et al., } 2002 \text { [111]; Bilgin } 2007 \text { [132]; } \\
\text { Duzlu et al., } 2011 \text { [133]; Yavuz et al., } 2011 \text { [134]; } \\
\text { Aktas and Ozubek } 2015 \text { [100]; Duzlu et al., } 2015 \text { [118]; } \\
\text { Kose et al., } 2017 \text { [116] }\end{array}$ \\
\hline \multirow{3}{*}{ B. bigemina } & ME & $0.6-32.2$ & $\begin{array}{c}\text { Mimioglu et al., } 1955 \text { [135]; Goksu et al., } 1959 \text { [120]; } \\
\text { Ozcan } 1961 \text { [136]; Hoffman et al., } 1971 \text { [137]; } \\
\text { Tüzer } 1981 \text { [122]; Dumanlı and Özer } 1987 \text { [138]; } \\
\text { Sayin e al., } 1989 \text { [127]; Inci } 1992 \text { [126]; Ozer et al., } 1993 \text { [123]; } \\
\text { Acıc1 } 1995 \text { [124]; Inci et al., } 2002 \text { [125] }\end{array}$ \\
\hline & $\mathrm{SM}$ & $0.9-80$ & $\begin{array}{l}\text { Cakmak 1987 [108]; Dincer et al., } 1991 \text { [139]; Eren } 1993 \text { [128]; } \\
\text { Sayın et al., 1996 [109]; Ica } 2004 \text { [129]; Vatansever et al., } \\
2003 \text { [114]; Cakmak and Oz } 1993 \text { [140]; Vatansever et al., } \\
2001 \text { [141]; Aktas et al., } 2001 \text { [130]; Sevinc et al., } 2001 \text { [142]; } \\
\text { Inci et al., } 2002 \text { [125]; Kaya et al., } 2006 \text { [143]; } \\
\text { Sayın et al., } 1996 \text { [109]; Ekici and Sevinc } 2009 \text { [33]; } \\
\text { Sevgili et al., } 2010 \text { [144]; Kalkan et al., } 2010 \text { [131] }\end{array}$ \\
\hline & MT & $0.6-18.2$ & $\begin{array}{c}\text { Tanyuksel et al., } 2002 \text { [111]; Ica } 2004 \text { [129]; Ica et al., } 2007 \text { [145]; } \\
\text { Altay et al., } 2008 \text { [115]; Duzlu et al., } 2011 \text { [133]; } \\
\text { Aktas and Ozubek } 2015 \text { [100]; Duzlu et al., } 2015 \text { [118]; } \\
\text { Zhou et al., } 2016 \text { [146] }\end{array}$ \\
\hline \multirow{3}{*}{ B. divergens } & ME & 0.8 & Aktas and Ozubek 2015 [100] \\
\hline & $\mathrm{SM}$ & $0.6-75$ & $\begin{array}{c}\text { Sayın et al., } 1996 \text { [109]; Aktas et al., } 2001 \text { [130]; } \\
\text { Inci et al., } 2002 \text { [125] }\end{array}$ \\
\hline & MT & $1.1-7.4$ & $\begin{array}{l}\text { Tanyüksel et al., } 2002 \text { [111]; Vatansever et al., } 2003 \text { [114]; } \\
\text { Aktas and Ozubek } 2015 \text { [100] }\end{array}$ \\
\hline B. major & MT & $0.2-0.5$ & Vatansever et al., 2003 [114]; Altay et al., 2008 [115] \\
\hline B. occultans & MT & 3 & Aktas et al., 2014 [100]; Aktas and Ozubek 2015 [100] \\
\hline Babesia spp. & MT & 1.3 & Altay et al., 2008 [115] \\
\hline Babesia spp. & MT & 3.3 & Kose et al., 2017 [116] \\
\hline Babesia sp. Sivas & MT & 1.9 & Altay et al., 2020 [117] \\
\hline
\end{tabular}

Abbreviations: ME, microscopic examination; SM, serologic methods; MT, molecular techniques.

No positive results have been reported so far regarding $B$. major by microscopy and serological methods in Turkey. In recent years, the molecular diagnostic of $B$. major based on RLB tests has been found a prevalence of $0.2 \%$ in the Ankara region [114] and $0.51 \%$ in the Eastern Black Sea Region [115] (Table 2 and Figure 1). Similar to B. major, only molecular data are available for B. ocultans and it was reported a prevalence of $3 \%$ for this Babesia species using RLB technique in samples from the Black Sea region [100]. In the same study, the authors reported cases of clinical babesisosis caused from B. bovis, B. bigemina, and B. divergens species. 
Additional studies have also showed the presence of new uncharacterized Babesia genotypes in cattle in Turkey. By using RLB technique, these studies have reported the occurrence of Babesia sp. CS58, Babesia spp., and Babesia sp. Sivas in cattle. Blast analysis indicated that their $18 \mathrm{~S}$ sequences are $99-100 \%$ identical to the $18 \mathrm{~S}$ gene of B. occultans [115-117] (Table 2). Considering these preliminary findings, further investigation is needed in order to precisely identify these currently uncharacterized Babesia organisms in the country and evaluate their implication on the development of bovine babesiosis.

Studies based on molecular methods have reported considerable sequence variations on some Babesia genes, such as RAP-1, MSA, and AMA-1. Using a combination of PCR and sequencing techniques, Duzlu et al. (2015) [118] showed that the sequences of the B. bovis MSA-2c gene in Turkish isolates are $7.5 \%$ different from other isolates in the world. This rate was found to be $0.5 \%$ in the B. bigemina RAP-1 gene. Another study focused on defining sequence polymorphisms of AMA-1 protein of in vivo and in vitro isolates of "Babesia bigemina Kayseri/Turkey" strain. The analysis revealed that nucleotide sequences of Kayseri/Turkey IV1 and Kayseri/Turkey IT2 isolates showed 99.7\% identity to each other with a single nucleotide mutation at the position 103. Interestingly, this non-synonymous mutation results in the change of the amino acid at the position 35 (Phe ${ }^{35}$ in Kayseri/Turkey IV1 and $\mathrm{Leu}^{35}$ in Kayseri/Turkey IT2) [119]. Implications of this finding need to be investigated in the light of epidemiological and immunopathological view of the disease.

In summary, bovine babesiosis has been reported using different diagnostic methods in all of Turkey's seven geographical regions (Figure 1). While B. bovis and B. bigemina are reported in all geographical regions, $B$. divergens has been found more in humid regions located near the seacoast. Despite these many epidemiological investigations, the number of case-based studies is very low. Therefore, prevalence and the actual economic impact of the disease on the livestock industry cannot be accurately assessed, due, in part, to the absence of a national program to systematically record cases of bovine babesiosis in Turkey. Consequently, more well-designed surveys based on highly sensitive assays are needed, especially in areas of the country that so far have received little attention. Although there is no study on annual economic losses associated with bovine babesiosis, the high incidence of the disease in geographical regions that are highly populated by cattle suggests that the disease is already causing serious costs to the livestock industry in Turkey. Clearly, all these findings together strongly suggest the need to organize coordinated efforts aimed at assessing the current status and the development of control measures of bovine babesiosis in Turkey.

\section{Current Gaps on Bovine Babesiosis Research in Turkey and Suggestions for Intervention}

Causative agents of transboundary animal diseases, such as bovine babesiosis, can be easily transported among countries with the increase in intercontinental animal trade [147-149]. The number of animals imported to Turkey from various countries has increased in recent years. Animals imported from countries such as Brazil and Australia that are endemic for bovine babesiosis should be tested in order to determine their status before being admitted into Turkey $[8,28]$. Therefore, there is a need to develop pan-Babesia direct and serological assays to be implemented in the country. However, there is a possibility that animals test positive for Babesia because they are vaccinated and/or infected with a virulent strain, since vaccination is a common practice in such endemic countries. Regardless of the type of Babesia strain infecting these imported animals, they potentially pose an important risk for Turkey's cattle industry. In these cases, additional practices are needed, such as quarantine to evaluate clinical signs of acute disease and examination for tick infestation, among others. These animal health practices increase the costs for the cattle industry that should be partially or totally covered by government's funds, or otherwise consumers would have to pay for it. Differentiating infected from vaccinated animals (DIVA) vaccines and diagnostic tests that can also differentiate imported vaccinated from naturally infected animals need to be urgently developed and implemented in the country. Importantly, tick control measurements need also to be performed in such imported animals. Lack of such control in the past resulted in the emergence of $R$. microplus, one of the most devastating vectors of Babesia species implicated in bovine babesiosis. Fortunately, R. microplus have not been 
found yet in Turkey, despite the importation of animals from places, such as Brazil and several African countries, where this tick species is endemic $[150,151]$. $R$. microplus has a major economic impact on milk and beef production in Brazil, and annual losses in this country were estimated at \$3.24 billion US dollars [151]. R. microplus tends to replace the local boophilic fauna after entering a new region and affects the epidemiology of bovine babesiosis. Rapid spread of $R$. microplus was observed in South Africa, Zambia, and East Africa [5]. Therefore, introduction of R. microplus can potentially dramatically change the future status of bovine babesiosis in Turkey. Thus, prevention measures as well as novel research are needed to address gaps in our understanding on the biology and ecology of this tick species in exotic and non-endemic environments.

Many novel Babesia genotypes or species have been recently reported in diverse vertebrates hosts worldwide [6]. Some of these species have also been reported in cattle in Turkey, but no detailed studies on parasite biology and host-parasite-tick interactions have been performed [115-117]. While making novel genotype discoveries, the $18 \mathrm{~S}$ gene region alone has been shown to be insufficient and additional sequencing analysis needs to be performed using other gene regions [5]. The impact, vectors, and pathogenicity of these newly reported genotypes or species of Babesia remain largely unknown in Turkey, and these factors need to be further characterized. A recent study in Sri Lanka reported the presence of a novel Babesia species, called Babesia sp. Mymensingh, which causes clinical babesiosis characterized by fever, hemoglobinuria, anemia, and jaundice in cattle [103,152]. Therefore, studies focused on detailed examination of biology, pathogenicity, host-parasite interactions will fill a large gap that, in turn, can help design strategies to control outbreaks of bovine babesiosis caused by newly, uncharacterized local parasites strains in Turkey.

Use of acaricides is the only method currently used for the prevention of bovine babesiosis in the country. Although there are studies on the efficacy of some acaricides (flumethrin, deltamethrin, cypermethrin) against ticks on cattle in Turkey, investigations on emerging acaricide-resistance in tick populations have not been performed [153,154]. Furthermore, acaricide applications in cattle are usually performed using poorly standardized and unhealthy procedures by breeders in Turkey, and this can potentially generate increased acaricide resistance by ticks due to dose errors as well as environmental and health problems. Livestock producers would benefit greatly from a national training program on the use of acaricides in cattle from the Turkish Ministry of Agriculture. In addition, acaricide applications can also be performed at certain intervals by the local official veterinarians in selected endemic areas. In this way, a more effective tick control program could provide a platform that, in turn, can help decrease the chances for development of acaricide resistance. Economic losses due to TBD can also be reduced by introducing defined policies and requirement for the application of acaricides to livestock, using the frame of existing support programs currently provided by the state, such as the Livestock Support Program.

To date, costs associated with bovine babesiosis in Turkey have not been yet estimated and this analysis is urgently needed. Proper estimation should include cattle mortality, abortions, losses in milk/meat production, loss of draft power, and expenses related to control measures, such as acaricide treatments, and the purchase of therapeutics, among other aspects. In addition, annual losses due to other costs related tick borne diseases (TBD) should also be calculated.

Functional, genetic, and immunological studies on Babesia genes and subunit vaccine candidate proteins will be needed in order to develop subunit vaccines, efficient and simpler point of care diagnostic tests, and other possible control methods. Such investigations would be much more relevant to Turkey if local parasites strains are included in comparison with other, more studied strains, such as the virulent T2Bo B. bovis strain [155]. Live vaccines are not currently available to prevent bovine babesiosis in the country; therefore, production of live vaccines based on parasites strains that are currently circulating in the country's provinces should increase control efficacy, prevent outbreaks, and decrease the use of acaricides. Thus, the need for such live vaccines to alleviate the load of bovine babesiosis in Turkey should be addressed and properly assessed. 
As a road for future directions on Babesia research, well-known and novel, uncharacterized parasite species preserve their mystery like an unconquered land, even after many years of exploration. Numerous characterization studies have been performed up to now and will continue until effective eradication of this parasite is accomplished. Along with genome analysis, important advances have been made in the biology of Babesia parasites globally [59,155-157]. Afterwards, transfection systems have been developed for gene modification and functional analysis to accelerate vaccine candidate discovery [156]. Together with novel gene editing technologies, these new approaches can potentially accelerate the development of efficient diagnostics and novel vaccine strategies, such as TBV based on Babesia sexual-stage antigens. It would be essential to develop a national research program in bovine babesiosis/Babesia to translate this new knowledge to the hands of research and field personnel involved in cattle production in Turkey. In vitro tick artificial feeding systems can also be developed and applied to better study tick-Babesia interactions [158]. With the development of this system, effectiveness of transstadial and transovarial transmission of many tick-borne pathogens can be determined. Importantly, tick artificial feeding systems can provide a framework for reducing and improving animal use to study ticks and tick-borne pathogens that are important for human and veterinary medicine [158]. Results of such research projects will greatly benefit the development and implementation of control strategies against bovine babesiosis in Turkey.

Subunit vaccines using recombinant antigens produced in Escherichia coli expression systems may or may not be efficient in eliciting protective immune responses against Babesia. Protection to Babesia is believed to be dependent on Th- 1 helper cells and early production of IFN $\gamma$, which requires adequate antigen presentation by professional antigen-presenting cells via major histocompatibility complex (MHC) class II and effective T cell responses. Perhaps effective subunit vaccines will require the use of mammalian expression, or transfection-based homologous parasite-specific expression systems for antigen production. In addition, as far as vaccine efficacy is concerned, nanoparticles, such as Immune stimulating complexes (ISCOM), are thought to be effective adjuvants for Babesia subunit vaccines, which opens new possibilities for the testing of candidate antigens [59].

Novel non-sophisticated point of care diagnostic methods that can be performed by untrained personnel are needed for the rapid "on site" detection of the disease in field conditions and may accelerate the time of response in severe outbreaks of bovine babesiosis. On the other hand, state-of-the-art technologies, such as next-generation and nanopore sequencing approaches, can help our understanding of the composition of local strains, population dynamics of the parasites, and help identify virulence factors that can be used for developing novel vaccines. These techniques combined with gene manipulation techniques already available for the transfection of Babesia parasites [156,159] may also lead to better defined and non-tick transmissible live vaccines incorporating DIVA markers to differentiate vaccinated from naturally-infected animals. These DIVA vaccines are much needed in Turkey, especially considering the importation of a large number of live cattle from countries that are endemic for bovine babesiosis.

Cattle imported into Turkey are currently not subjected to strict sanitary controls, including checking for ticks and TBD, thus imposing an important risk for the development of cattle industries in the country. Such controls need to be incorporated in order to prevent the importation of exotic ticks and Babesia strains in the country. As stated before, the introduction of novel tick species that are competent for Babesia, such as R. microplus, would have devastating consequences, given the ability to these ectoparasites to develop resistance to acaricides, and the lack of alternatives for efficient anti-tick vaccines.

To eliminate the negative effects of acaricides, effective anti-tick vaccine formulations need to be developed based on protective antigens using new generation adjuvants, such as nanoparticles [160]. By combining protective epitopes from different tick proteins into a single chimeric antigen, new vaccines may be likely to target more than one ectoparasite species and host [161]. In addition, microspheres and other sustained-release technologies could also be integrated into acaricides to offer a potential solution for its downside effects. Importantly, new generation sequencing methods can also help 
identify parasites and other infectious organisms present in distinct tick populations and facilitate our understanding of the interplay among Babesia parasites and tick vectors in the ecosystem. Development of new methods for the detection of tick-infested cattle may also help in the control of TBD, including bovine babesiosis.

Collectively, these new technologies and research directions can potentially reveal bottlenecks on the Babesia lifecycle and tick ecology that will help implement strategies to control bovine babesiosis to benefit the cattle industry worldwide and particularly in Turkey.

\section{Concluding Remarks}

The world population has been increasing exponentially since the 1950s and nowadays, there is a need to efficiently produce high amounts of animal protein and fiber, and consequently, different human and animal health problems may arise. Protein sources are becoming more valuable every day and an effective and safe method of protection against Babesia parasites that affect millions of cattle every year has become more important than ever. Based on the limited data available, it is possible to infer that bovine babesiosis caused by distinct Babesia spp. as well as novel and newly identified Babesia genotypes/species is highly prevalent throughout Turkey, and safe and effective methods are urgently needed to combat this disease. For this purpose, firstly, multidisciplinary studies need to be performed nationally to address the economic and social impact of bovine babesiosis in Turkey. Secondly, the need for live vaccines should be carefully evaluated, and if needed, vaccines should be produced based on strains of the parasite that are circulating in the country. Use of acaricides, and combinations of these drugs, should be used consciously by technical personnel as part of developed control strategies and practices. In addition, further basic studies on parasite and tick biology need to be performed to develop rationally designed recombinant vaccines. We also should take advantage of newly emerging technologies in order to develop sophisticated tools required to control Babesia, a highly co-evolved parasite that is able to evade so efficiently the host immune system and optimize control measures that are currently available. The Turkish cattle industry and, in turn the entire country's economy, will greatly benefit from such control strategies against the devastating effects of bovine babesiosis.

Author Contributions: Conceptualization, C.E.S., S.O. and R.G.B.; formal analysis, C.E.S., R.G.B., S.O., H.F.A., A.I. and M.A.; investigation, C.E.S., R.G.B., S.O., H.F.A., A.I. and M.A.; writing-original draft preparation, C.E.S., S.O., R.G.B.; writing-review and editing, C.E.S., R.G.B., S.O., H.F.A., A.I. and M.A.; visualization, S.O.; supervision, C.E.S.; project administration, C.E.S.; funding acquisition, C.E.S., R.G.B. All authors have read and agreed to the published version of the manuscript

Funding: This work was supported by The Scientific and Technological Council of Turkey (TUBITAK) 2219 Grant Program. This work was also supported by the United States Department of Agriculture-Agriculture Research Service-Current Research Information System Project No. 2090-32000-039-00D and the USDA National Institute of Food and Agriculture (Award Number: 2020-67015-31809; Proposal Number: 2019-05375, Accession Number: 1022541).

Conflicts of Interest: None of the authors has declared a conflict of interest.

\section{References}

1. Babes, V. Sur l'hémoglobinurie bactérienne du boeuf. CR Acad. Sci. Paris 1888, 107, 692-694.

2. Mihalca, A.D.C.; Suteu, E.V.; Marinculic, A.; Boireanu, P. The quest for piroplasms: From babes to smith to molecules. Sci. Parasitol. 2010, 11, 14-19.

3. Smith, T.; Kilbourne, F.L. Investigations into the Nature, Causation, and Prevention of Texas or Southern Cattle Fever, 8th and 9th Reports; U.S. Department of Agriculture, Bureau of Animal Industry: Washington, DC, USA, 1893.

4. Suarez, C.E.; Noh, S. Emerging perspectives in the research of bovine babesiosis and anaplasmosis. Vet. Parasitol. 2011, 180, 109-125. [CrossRef] [PubMed]

5. Gray, J.S.; Estrada-Peña, A.; Zintl, A. Vectors of Babesiosis. Annu. Rev. Èntomol. 2019, 64, 149-165. [CrossRef] [PubMed]

6. Schnittger, L.; Rodriguez, A.E.; Florin-Christensen, M.; Morrison, D.A. Babesia: A world emerging. Infect. Genet. Evol. 2012, 12, 1788-1809. [CrossRef] [PubMed] 
7. Uilenberg, G. Babesia-A historical overview. Vet. Parasitol. 2006, 138, 3-10. [CrossRef]

8. Bock, R.; Jackson, L.; De Vos, A.; Jorgensen, W. Babesiosis of cattle. Parasitology 2004, 129, S247-S269. [CrossRef] [PubMed]

9. Brown, W.C.; Estes, D.M.; Chantler, S.E.; Kegerreis, K.A.; Suarez, C.E. DNA and a CpG Oligonucleotide Derived from Babesia bovis Are Mitogenic for Bovine B Cells. Infect. Immun. 1998, 66, 5423-5432. [CrossRef] [PubMed]

10. Brown, W.C.; Norimine, J.; Goff, W.L.; Suarez, C.E.; McElwain, T.F. Prospects for recombinant vaccines against Babesia bovis and related parasites. Parasite Immunol. 2006, 28, 315-327. [CrossRef]

11. Gallego-Lopez, G.M.; Cooke, B.M.; Suarez, C.E. Interplay between Attenuation- and Virulence-Factors of Babesia bovis and Their Contribution to the Establishment of Persistent Infections in Cattle. Pathogens 2019, 8, 97. [CrossRef]

12. Shoda, L.K.M.; Palmer, G.H.; Florin-Christensen, J.; Florin-Christensen, M.; Godson, D.L.; Brown, W.C. Babesia bovis-Stimulated Macrophages Express Interleukin-1 $\beta$, Interleukin-12, Tumor Necrosis Factor Alpha, and Nitric Oxide and Inhibit Parasite Replication In Vitro. Infect. Immun. 2000, 68, 5139-5145. [CrossRef] [PubMed]

13. Goff, W.; Storset, A.K.; Johnson, W.C.; Brown, W.C. Bovine splenic NK cells synthesize IFN-gamma in response to IL-12-containing supernatants from Babesia bovis-exposed monocyte cultures. Parasite Immunol. 2006, 28, 221-228. [CrossRef] [PubMed]

14. Brown, W.C.; Logan, K.S. Babesia bovis: Bovine helper T cell lines reactive with soluble and membrane antigens of merozoites. Exp. Parasitol. 1992, 74, 188-199. [CrossRef]

15. Wright, I.G.; Goodger, B.V.; Leatch, G.; Aylward, J.H.; Rode-Bramanis, K.; Waltisbuhl, D.J. Protection of Babesia bigemina-immune animals against subsequent challenge with virulent Babesia bovis. Infect. Immun. 1987, 55, 364-368. [CrossRef] [PubMed]

16. Homer, M.J.; Aguilar-Delfin, I.; Telford, S.R.; Krause, P.J.; Persing, D.H. Babesiosis. Clin. Microbiol. Rev. 2000, 13, 451-469. [CrossRef] [PubMed]

17. Florin-Christensen, M.; Suarez, C.E.; Rodriguez, A.E.; Flores, D.A.; Schnittger, L. Vaccines against bovine babesiosis: Where we are now and possible roads ahead. Parasitology 2014, 141, 1563-1592. [CrossRef]

18. Ganzinelli, S.R.; Schnittger, L.A.E.; Florin-Christensen, M. Babesia of Domestic Ruminants. In Parasitic Protozoa of Farm Animals and Pets; Florin-Christensen, M., Ed.; Springer Nature: Berlin, Germany, 2018; pp. 215-239.

19. Zintl, A.; Mulcahy, G.; Skerrett, H.E.; Taylor, S.M.; Gray, J.S. Babesia divergens, a Bovine Blood Parasite of Veterinary and Zoonotic Importance. Clin. Microbiol. Rev. 2003, 16, 622-636. [CrossRef]

20. Thomas, S.E.; Mason, T.E. Isolation and transmission of an unidentified Babesia sp. infective for cattle. Onderstepoort J. Vet. Res. 1981, 48, 155-158.

21. De Waal, D.T.; Potgieter, F.T.; Combrink, M.P.; Mason, T.E. The isolation and transmission of an unidentified Babesia sp. to cattle by Hyalomma truncatum Koch 1844. Onderstepoort J. Vet. Res. 1990, 57, 229-232.

22. Ohta, M.; Tsuji, M.; Tsuji, N.; Fujisaki, K. Morphological, Serological and Antigenic Characteristics, and Protein Profile of Newly Isolated Japanese Bovine Babesia Parasite with Particular Reference to Those of B. ovata. J. Vet. Med. Sci. 1995, 57, 671-675. [CrossRef]

23. Luo, J.; Yin, H.; Liu, Z.; Yang, D.; Guan, G.; Liu, A.; Ma, M.; Dang, S.; Lu, B.; Sun, C.; et al. Molecular phylogenetic studies on an unamed bovine Babesia sp. based on small subunit ribosomal RNA gene sequences. Vet. Parasitol. 2005, 133, 1-6. [CrossRef] [PubMed]

24. Aktas, M. A survey of ixodid tick species and molecular identification of tick-borne pathogens. Vet. Parasitol. 2014, 200, 276-283. [CrossRef] [PubMed]

25. Inci, A.; Yildirim, A.; Düzlü, O.; Doganay, M.; Aksoy, S. Tick-Borne Diseases in Turkey: A Review Based on One Health Perspective. PLoS Neglected Trop. Dis. 2016, 10, e0005021. [CrossRef] [PubMed]

26. Sevinc, F.; Xuan, X. Major tick-borne parasitic diseases of animals: A frame of references in Turkey. Eurasian J. Vet. Sci. 2015, 31, 132. [CrossRef]

27. Turkstat. Turkısh Statistical Institute, I.A. Available online: http://www.turkstat.gov.tr/ (accessed on 5 May 2020).

28. Pupin, R.C.; Guizelini, C.D.C.; De Lemos, R.A.A.; Martins, T.B.; Borges, F.D.A.; Borges, D.G.L.; Gomes, D.C. Retrospective study of epidemiological, clinical and pathological findings of bovine babesiosis in Mato Grosso do Sul, Brazil (1995-2017). Ticks Tick-Borne Dis. 2019, 10, 36-42. [CrossRef] 
29. Graham, O.H.; Hourrigan, J.L. Review Article1: Eradication Programs for the Arthropod Parasites of Livestock2. J. Med. Èntomol. 1977, 13, 629-658. [CrossRef]

30. Esteve-Gasent, M.D.; Rodríguez-Vivas, R.I.; Medina, R.F.; Ellis, D.; Schwartz, A.; Garcia, B.C.; Hunt, C.; Tietjen, M.; Bonilla, D.; Thomas, D.; et al. Research on Integrated Management for Cattle Fever Ticks and Bovine Babesiosis in the United States and Mexico: Current Status and Opportunities for Binational Coordination. Pathogens 2020, 9, 871. [CrossRef]

31. De León, A.A.P.; Teel, P.D.; Auclair, A.N.; Messenger, M.T.; Guerrero, F.D.; Schuster, G.; Miller, R.J. Integrated Strategy for Sustainable Cattle Fever Tick Eradication in USA Is Required to Mitigate the Impact of Global Change. Front. Physiol. 2012, 3. [CrossRef]

32. León, A.A.P.D.; Strickman, D.; Knowles, D.P.; Fish, D.; Thacker, E.L.; De La Fuente, J.; Krause, P.J.; Wikel, S.K.; Miller, R.S.; Wagner, G.G.; et al. One Health approach to identify research needs in bovine and human babesioses: Workshop report. Parasites Vectors 2010, 3. [CrossRef]

33. Ekici, O.D.; Sevinc, F. Seroepidemiology of Babesia bigemina in Cattle in the Konya Province, Turkey: Endemic Status. B. Vet. I. Pulawy. 2009, 53, 645-649.

34. Inci, A.; Ica, A.; Yildirim, A.; Vatansever, Z.; Cakmak, A.; Albasan, H.; Cam, Y.; Atasever, A.; Sariozkan, S.; Duzlu, O. Economical impact of tropical theileriosis in the Cappadocia region of Turkey. Parasitol. Res. 2007, 101, 171-174. [CrossRef] [PubMed]

35. Rodriguez, A.E.S.; Tomazic, M.L.L.; Florin-Christensen, M. Current and Prospective Tools for the Control of Cattle-Infecting Babesia Parasites. In Protozoa: Biology, Classification and Role in Disease; Castillo, V., Harris, R., Eds.; Nova Publishers: Hauppauge, NY, USA, 2013; pp. 1-44.

36. Hadani, A.P.E.; Tsafrir, N.; Rauchbach, K.; Mayer, E. The transmission of Babesia bigemina and Babesiella berbera and Anaplasma centrale by Boophilus annulatus (Say). Refuah Vet. 1974, 31, 149-154.

37. Mahoney, D.; Mirre, G. A note on the transmission of Babesia bovis (syn B. argentina) by the one-host tick, Boophilus microplus. Res. Vet. Sci. 1979, 26, 253-254. [CrossRef]

38. Smith, R.; Osorno, B.; Brener, J.; De La Rosa, R.; Ristic, M. Bovine babesiosis: Severity and reproducibility of Babesia bovis infections induced by Boophilus microplus under laboratory conditions. Res. Vet. Sci. 1978, 24, 287-292. [CrossRef]

39. Callow, L.L. The infection of Boophilus microplus with Babesia bigemina. Parasitology 1968, 58, 663-670. [CrossRef] [PubMed]

40. Morzaria, S.P.; Young, A.S.; Hudson, E.B. Babesia bigemina in Kenya: Experimental transmission by Boophilus decoloratus and the production of tick-dervied stabilates. Parasitology 1977, 74, 291-298. [CrossRef]

41. Büscher, G. The infection of various tick species with Babesia bigemina, its transmission and identification. Parasitol. Res. 1988, 74, 324-330. [CrossRef]

42. Donnelly, J.; Peirce, M. Experiments on the transmission of Babesia divergens to cattle by the tick Ixodes ricinus. Int. J. Parasitol. 1975, 5, 363-367. [CrossRef]

43. Gray, J.S.; De Vos, A.J. Studies on a bovine Babesia transmitted by Hyalomma marginatum rufipes Koch, 1844 . Onderstepoort J. Vet. Res. 1981, 48, 215-223.

44. Ma, L.H.L.; Zhao, J.L. An investigation of water buffalo babesiosis in Hubei province V. adult Rhipicephalus haemaphysaloides transmits the parasites transovarially. Chin. J. Anim. Vet. Sci. 1989, 1, 67-70.

45. Takahashi,K.W.; Kawai, S.A.; Yokota,H.; Kurosawa, T.; Sonoda, M. Investigation of isolation, transmission and virulence of bovine Babesia sp. in Hokkaido. J. Coll. Dairying 1983, 10, 171-181.

46. Aydin, L.; Bakirci, S. Geographical distribution of ticks in Turkey. Parasitol. Res. 2007, 101, 163-166. [CrossRef] [PubMed]

47. Aktas, M.; Altay, K.; Ozubek, S.; Dumanl1, N. A survey of ixodid ticks feeding on cattle and prevalence of tick-borne pathogens in the Black Sea region of Turkey. Vet. Parasitol. 2012, 187, 567-571. [CrossRef] [PubMed]

48. Ica, A.; Vatansever, Z.; Yildirim, A.; Duzlu, O.; Inci, A. Detection of Theileria and Babesia species in ticks collected from cattle. Vet. Parasitol. 2007, 148, 156-160. [CrossRef] [PubMed]

49. Meyilli, T.D.; Yildirim, A.O.; Onder, Z.; Ciloglu, A.; Inci, A. Investigation of Babesia bovis and Babesia bigemina by real time pcr in tick species collected from cattle in Kayseri province. Erciyes Üniv. Vet. Fak Derg 2016, 13, 201-208. 
50. Aktas, M.; Vatansever, Z.; Ozubek, S. Molecular evidence for trans-stadial and transovarial transmission of Babesia occultans in Hyalomma marginatum and Rhipicephalus turanicus in Turkey. Vet. Parasitol. 2014, 204, 369-371. [CrossRef] [PubMed]

51. Orkun, Ö.; Çakmak, A.; Nalbantoğlu, S.; Karaer, Z. Turkey tick news: A molecular investigation into the presence of tick-borne pathogens in host-seeking ticks in Anatolia; Initial evidence of putative vectors and pathogens, and footsteps of a secretly rising vector tick, Haemaphysalis parva. Ticks Tick-Borne Dis. 2020, 11. [CrossRef]

52. Callow, L.; Mellors, L.; McGregor, W. Reduction in virulence of Babesia bovis due to rapid passage in splenectomized cattle. Int. J. Parasitol. 1979, 9, 333-338. [CrossRef]

53. Dalgliesh, R.J.; Callow, L.L.; Mellors, L.T.; McGregor, W. Development of a highly infective Babesia bigemina vaccine of reduced virulence. Aust. Vet. J. 1981, 57, 8-11. [CrossRef]

54. Pedroni, M.J.; Sondgeroth, K.S.; Gallego-Lopez, G.M.; Echaide, I.; Lau, A.O.T. Comparative transcriptome analysis of geographically distinct virulent and attenuated Babesia bovis strains reveals similar gene expression changes through attenuation. BMC Genom. 2013, 14. [CrossRef]

55. Gallego-Lopez, G.M.; Lau, A.O.T.; Brown, W.C.; Johnson, W.C.; Ueti, M.W.; Suarez, C.E. Spherical Body Protein 2 truncated copy 11 as a specific Babesia bovis attenuation marker. Parasites Vectors 2018, 11, 1-8. [CrossRef] [PubMed]

56. Späth, E.; Mangold, A.J.; Guglielmone, A. Estimation of the potential demand for a bovine babesiosis and anaplasmosis vaccine in argentina. Vet. Parasitol. 1990, 36, 131-140. [CrossRef]

57. Ojeda, J.J.; Orozco, L.; Flores, R.; Rojas, C.; Figueroa, J.V.; Martínez, J.A.A. Validation of an Attenuated Live Vaccine against Babesiosis in Native Cattle in an Endemic Area. Transbound. Emerg. Dis. 2010, 57, 84-86. [CrossRef] [PubMed]

58. Alzan, H.F.; Cooke, B.M.; Suarez, C.E. Transgenic Babesia bovis lacking 6-Cys sexual-stage genes as the foundation for non-transmissible live vaccines against bovine babesiosis. Ticks Tick-Borne Dis. 2019, 10, 722-728. [CrossRef] [PubMed]

59. Rathinasamy, V.; Poole, W.A.; Bastos, R.G.; Suarez, C.E.; Cooke, B.M. Babesiosis Vaccines: Lessons Learned, Challenges Ahead, and Future Glimpses. Trends Parasitol. 2019, 35, 622-635. [CrossRef] [PubMed]

60. Sibinovic, K.H.; Sibinovic, S.; Ristic, M.; Cox, H.W. Immunogenic Properties of Babesial Serum Antigens. J. Parasitol. 1967, 53, 1121. [CrossRef]

61. Montenegro-James, S.; Meuwissen, J. Immunoprophylactic control of bovine babesiosis: Role of exoantigens of Babesia. Trans. R. Soc. Trop. Med. Hyg. 1989, 83, 85-94. [CrossRef]

62. Moreau, Y.; Vidor, E.; Bissuel, G.; Dubreuil, N. Vaccination against canine babesiosis: An overview of field observations. Trans. R. Soc. Trop. Med. Hyg. 1989, 83, 95-96. [CrossRef]

63. Valentin, A.; Precigout, E.; L'Hostis, M.; Carcy, B.; Gorenflot, A.; Schrevel, J. Cellular and humoral immune responses induced in cattle by vaccination with Babesia divergens culture-derived exoantigens correlate with protection. Infect. Immun. 1993, 61, 734-741. [CrossRef]

64. Zhao, J.; Liu, Z.; Yao, B.; Ma, L. Culture-derived Babesia orientalis exoantigens used as a vaccine against buffalo babesiosis. Parasitol. Res. 2002, 88, S38-S40. [CrossRef]

65. Bastos, R.G.; Suarez, C.E.; Laughery, J.M.; Johnson, W.C.; Ueti, M.W.; Knowles, D.P. Differential Expression of Three Members of the Multidomain Adhesion CCp Family in Babesia bigemina, Babesia bovis and Theileria equi. PLoS ONE 2013, 8, e67765. [CrossRef] [PubMed]

66. Hussein, H.E.; Bastos, R.G.; Schneider, D.A.; Johnson, W.C.; Adham, F.K.; Davis, W.C.; Laughery, J.M.; Herndon, D.R.; Alzan, H.F.; Ueti, M.W.; et al. The Babesia bovis hap2 gene is not required for blood stage replication, but expressed upon in vitro sexual stage induction. PLoS Neglected Trop. Dis. 2017, 11, e0005965. [CrossRef] [PubMed]

67. Wu, Y.; Ellis, R.D.; Shaffer, D.; Fontes, E.; Malkin, E.M.; Mahanty, S.; Fay, M.P.; Narum, D.L.; Rausch, K.; Miles, A.P.; et al. Phase 1 Trial of Malaria Transmission Blocking Vaccine Candidates Pfs25 and Pvs25 Formulated with Montanide ISA 51. PLoS ONE 2008, 3, e2636. [CrossRef] [PubMed]

68. Alzan, H.F.; Lau, A.O.T.; Knowles, D.P.; Herndon, D.R.; Ueti, M.W.; Scoles, G.A.; Kappmeyer, L.S.; Suarez, C.E. Expression of 6-Cys Gene Superfamily Defines Babesia bovis Sexual Stage Development within Rhipicephalus microplus. PLoS ONE 2016, 11, e0163791. [CrossRef]

69. Bohaliga, G.A.R.; Johnson, W.C.; Taus, N.S.; Hussein, H.E.; Bastos, R.G.; Suarez, C.E.; Scoles, G.A.; Ueti, M.W. Identification of proteins expressed by Babesia bigemina kinetes. Parasites Vectors 2019, 12, 271. [CrossRef] 
70. Camacho-Nuez, M.; Hernández-Silva, D.J.; Castañeda-Ortiz, E.J.; Paredes-Martínez, M.E.; Rocha-Martínez, M.K.; Álvarez-Sánchez, M.E.; Mercado-Curiel, R.F.; Aguilar-Tipacamú, G.; Gualito, J.M. Hap2, a novel gene in Babesia bigemina is expressed in tick stages, and specific antibodies block zygote formation. Parasites Vectors 2017, 10, 568. [CrossRef]

71. Fish, L.; Leibovich, B.; Krigel, Y.; McElwain, T.; Shkap, V. Vaccination of cattle against B. bovis infection with live attenuated parasites and non-viable immunogens. Vaccine 2008, 26, G29-G33. [CrossRef]

72. Alvarez, J.A.; Lopez, U.; Rojas, C.; Borgonio, V.M.; Sanchez, V.; Castañeda, R.; Vargas, P.; Figueroa-Millán, J.V. Immunization of Bos taurus Steers with Babesia bovis Recombinant Antigens MSA-1, MSA-2c and 12D3. Transbound. Emerg. Dis. 2010, 57, 87-90. [CrossRef]

73. Gaffar, F.R.; Yatsuda, A.P.; Franssen, F.F.; De Vries, E. A Babesia bovis merozoite protein with a domain architecture highly similar to the thrombospondin-related anonymous protein (TRAP) present in Plasmodium sporozoites. Mol. Biochem. Parasitol. 2004, 136, 25-34. [CrossRef]

74. Gaffar, F.R.; Yatsuda, A.P.; Franssen, F.F.J.; De Vries, E. Erythrocyte Invasion by Babesia bovis Merozoites Is Inhibited by Polyclonal Antisera Directed against Peptides Derived from a Homologue of Plasmodium falciparum Apical Membrane Antigen 1. Infect. Immun. 2004, 72, 2947-2955. [CrossRef]

75. Torina, A.; Agnone, A.; Sireci, G.; Mosqueda, J.J.; Blanda, V.; Albanese, I.; La Farina, M.; Cerrone, A.; Cusumano, F.; Caracappa, S. Characterization of the Apical Membrane Antigen-1 in Italian Strains of Babesia bigemina. Transbound. Emerg. Dis. 2010, 57, 52-56. [CrossRef] [PubMed]

76. De La Fuente, J.; Kopáček, P.; Lew-Tabor, A.; Maritz-Olivier, C. Strategies for new and improved vaccines against ticks and tick-borne diseases. Parasite Immunol. 2016, 38, 754-769. [CrossRef] [PubMed]

77. Karunaratne, S.H.P.P. Insecticide resistance in insects: A review. Cey. J. Sci. (Bio. Sci.) 1998, 25, 72-99.

78. De La Fuente, J. Controlling ticks and tick-borne diseases looking forward. Ticks Tick-Borne Dis. 2018, 9, 1354-1357. [CrossRef] [PubMed]

79. Guerrero, F.D.; Miller, R.J.; De León, A.A.P. Cattle tick vaccines: Many candidate antigens, but will a commercially viable product emerge? Int. J. Parasitol. 2012, 42, 421-427. [CrossRef] [PubMed]

80. De La Fuente, J.; Rodríguez, M.; Montero, C.V.; Redondo, M.L.; García-García, J.C.; Méndez, L.; Serrano, E.; Valdes, M.; Enríquez, A.; Canales, M.; et al. Vaccination against ticks (Boophilus spp.): The experience with the Bm86-based vaccine Gavac ${ }^{\mathrm{TM}}$. Genet. Anal. Biomol. Eng. 1999, 15, 143-148. [CrossRef]

81. Suarez, M.; Rubi, J.; Perez, D.; Cordova, V.; Salazar, Y.; Vielma, A.; Barrios, F.; Gil, C.A.; Segura, N.; Carrillo, Y.; et al. High impact and effectiveness of Gavac ${ }^{\mathrm{TM}}$ vaccine in the national program for control of bovine ticks Rhipicephalus microplus in Venezuela. Livest. Sci. 2016, 187, 48-52. [CrossRef]

82. De La Fuente, J.; Almazán, C.; Canales, M.; De La Lastra, J.M.P.; Kocan, K.M.; Willadsen, P. A ten-year review of commercial vaccine performance for control of tick infestations on cattle. Anim. Health Res. Rev. 2007, 8, 23-28. [CrossRef]

83. De La Fuente, J. Vaccines for vector control: Exciting possibilities for the future. Vet. J. 2012, 194, 139-140. [CrossRef]

84. De La Fuente, J.; Merino, O. Vaccinomics, the new road to tick vaccines. Vaccine 2013, 31, 5923-5929. [CrossRef]

85. Merino, O.; Antunes, S.; Gualito, J.M.; Moreno-Cid, J.A.; De La Lastra, J.M.P.; Rosario-Cruz, R.; Rodríguez, S.; Domingos, A.; De La Fuente, J.; Rosario-Cruz, R. Vaccination with proteins involved in tick-pathogen interactions reduces vector infestations and pathogen infection. Vaccine 2013, 31, 5889-5896. [CrossRef] [PubMed]

86. Merino, O.; Almazán, C.; Canales, M.; Villar, M.; Moreno-Cid, J.A.; Galindo, R.C.; De La Fuente, J. Targeting the tick protective antigen subolesin reduces vector infestations and pathogen infection by Anaplasma marginale and Babesia bigemina. Vaccine 2011, 29, 8575-8579. [CrossRef] [PubMed]

87. Gualito, J.M.; Olvera-Ramirez, A.; Aguilar-Tipacamu, G.; Canto, G.J. Current Advances in Detection and Treatment of Babesiosis. Curr. Med. Chem. 2012, 19, 1504-1518. [CrossRef]

88. Pritchard, J.R.; Bruno, P.M.; Gilbert, L.A.; Capron, K.L.; Lauffenburger, D.A.; Hemann, M.T. Defining principles of combination drug mechanisms of action. Proc. Natl. Acad. Sci. USA 2013, 110, E170-E179. [CrossRef]

89. Chou, T.-C. Drug Combination Studies and Their Synergy Quantification Using the Chou-Talalay Method. Cancer Res. 2010, 70, 440-446. [CrossRef] 
90. Rizk, M.A.; El-Sayed, S.A.E.-S.; Terkawi, M.A.; Youssef, M.A.; Said, E.S.E.S.E.; Elsayed, G.; El-Khodery, S.; El-Ashker, M.; Elsify, A.; Omar, M.; et al. Optimization of a Fluorescence-Based Assay for Large-Scale Drug Screening against Babesia and Theileria Parasites. PLoS ONE 2015, 10, e0125276. [CrossRef]

91. Silva, M.G.; Domingos, A.; Esteves, M.A.; Cruz, M.; Suarez, C.E. Evaluation of the growth-inhibitory effect of trifluralin analogues on in vitro cultured Babesia bovis parasites. Int. J. Parasitol. Drugs Drug Resist. 2013, 3, 59-68. [CrossRef]

92. Silva, M.G.; Villarino, N.F.; Knowles, D.P.; Suarez, C.E. Assessment of Draxxin ${ }^{\circledR}$ (tulathromycin) as an inhibitor of in vitro growth of Babesia bovis, Babesia bigemina and Theileria equi. Int. J. Parasitol. Drugs Drug Resist. 2018, 8, 265-270. [CrossRef]

93. Tayebwa, D.S.; Tuvshintulga, B.; Guswanto, A.; Nugraha, A.B.; Batiha, G.E.-S.; Gantuya, S.; Rizk, M.A.; Vudriko, P.; Sivakumar, T.; Yokoyama, N.; et al. The effects of nitidine chloride and camptothecin on the growth of Babesia and Theileria parasites. Ticks Tick-Borne Dis. 2018, 9, 1192-1201. [CrossRef]

94. Tuvshintulga, B.; Aboulaila, M.; Davaasuren, B.; Ishiyama, A.; Sivakumar, T.; Yokoyama, N.; Iwatsuki, M.; Otoguro, K.; Ōmura, S.; Igarashi, I. Clofazimine Inhibits the Growth of Babesia and Theileria ParasitesIn VitroandIn Vivo. Antimicrob. Agents Chemother. 2016, 60, 2739-2746. [CrossRef]

95. Tuvshintulga, B.; Aboulaila, M.; Sivakumar, T.; Tayebwa, D.S.; Gantuya, S.; Naranbaatar, K.; Ishiyama, A.; Iwatsuki, M.; Otoguro, K.; Ōmura, S.; et al. Chemotherapeutic efficacies of a clofazimine and diminazene aceturate combination against piroplasm parasites and their AT-rich DNA-binding activity on Babesia bovis. Sci. Rep. 2017, 7, 13888. [CrossRef] [PubMed]

96. Guswanto, A.; Sivakumar, T.; Rizk, M.A.; Elsayed, S.A.E.; Youssef, M.A.; Elsaid, E.E.S.; Yokoyama, N.; Igarashi, I. Evaluation of a Fluorescence-Based Method for Antibabesial Drug Screening. Antimicrob. Agents Chemother. 2014, 58, 4713-4717. [CrossRef] [PubMed]

97. Jalovecká, M.; Hartmann, D.; Miyamoto, Y.; Eckmann, L.; Hajdusek, O.; O’Donoghue, A.J.; Sojka, D. Validation of Babesia proteasome as a drug target. Int. J. Parasitol. Drugs Drug Resist. 2018, 8, 394-402. [CrossRef] [PubMed]

98. El-Sayed, S.A.E.-S.; Rizk, M.A.; Yokoyama, N.; Igarashi, I. Evaluation of the in vitro and in vivo inhibitory effect of thymoquinone on piroplasm parasites. Parasites Vectors 2019, 12, 37. [CrossRef] [PubMed]

99. Rizk, M.A.; El-Sayed, S.A.E.-S.; Nassif, M.; Gualito, J.M.; Xuan, X.; Igarashi, I. Assay methods for in vitro and in vivo anti-Babesia drug efficacy testing: Current progress, outlook, and challenges. Vet. Parasitol. 2020, 279. [CrossRef] [PubMed]

100. Aktas, M.; Ozubek, S. Molecular and Parasitological Survey of Bovine Piroplasms in the Black Sea Region, Including the First Report of Babesiosis Associated with Babesia divergensin Turkey. J. Med. Èntomol. 2015, 52, 1344-1350. [CrossRef]

101. Wang, G.; Wormser, G.P.; Zhuge, J.; Villafuerte, P.; Ip, D.; Zeren, C.; Fallon, J.T. Utilization of a real-time PCR assay for diagnosis of Babesia microti infection in clinical practice. Ticks Tick-Borne Dis. 2015, 6, 376-382. [CrossRef]

102. Ozubek, S.; Aktas, M. Molecular evidence of a new Babesia sp. in goats. Vet. Parasitol. 2017, 233, 1-8. [CrossRef]

103. Roy, B.C.; Krücken, J.; Ahmed, J.S.; Majumder, S.; Baumann, M.P.; Clausen, P.-H.; Nijhof, A.M. Molecular identification of tick-borne pathogens infecting cattle in Mymensingh district of Bangladesh reveals emerging species of Anaplasma and Babesia. Transbound. Emerg. Dis. 2017, 65, e231-e242. [CrossRef]

104. Kim, C.-M.; Yokoyama, N.; Blanco, L.B.C.; Iseki, H.; Igarashi, I.; Xuan, X.; Alhassan, A. Development of a rapid immunochromatographic test for simultaneous serodiagnosis of bovine babesioses caused by Babesia bovis and Babesia bigemina. Am. J. Trop. Med. Hyg. 2008, 78, 117-121. [CrossRef]

105. Guswanto, A.; Allamanda, P.; Mariamah, E.S.; Munkjargal, T.; Tuvshintulga, B.; Takemae, H.; Sivakumar, T.; Aboulaila, M.; Terkawi, M.A.; Ichikawa-Seki, M.; et al. Evaluation of immunochromatographic test (ICT) strips for the serological detection of Babesia bovis and Babesia bigemina infection in cattle from Western Java, Indonesia. Vet. Parasitol. 2017, 239, 76-79. [CrossRef] [PubMed]

106. Tayebwa, D.S.; Beshbishy, A.M.; Batiha, G.E.-S.; Komugisha, M.; Byaruhanga, J.; Vudriko, P.; Yahia, R.; Alkazmi, L.; Hetta, H.F.; Yokoyama, N.; et al. Assessing the Immunochromatographic Test Strip for Serological Detection of Bovine Babesiosis in Uganda. Microorganisms 2020, 8, 1110. [CrossRef]

107. Curasson, D.A. Famille des Piroplasmides. In Traite de Parasitologie Veterinare et Comparee; Freres, V., Ed.; Tome III: Paris, France, 1943; pp. 160-190. 
108. Cakmak, A. Untersuchungen zur Inzidenz von Haemoparasiten in der Provinz Ankara; Tieraerztliche Hochschule Hannover: Hanover, Germany, 1987.

109. Sayın, F.D.Ş.; Karaer, Z.; Çakmak, A.; İnci, A.; Yukarı, B.A.; Eren, H.; Friehoff, K.T.; Müler, I. Studies of Sero-Prevalence Babesia Infection of Cattle in Turkey. In New Dimensions in Parasitology; Ozcel, M.A., Ed.; Turkish Society for Parasitology: İzmir, Turkey, 1996; Volume 20, pp. 505-516.

110. Oncel, T.; Vural, G.; Karaer, Z.; Çakmak, A.; Yurtalan, S.; Öz, İ.; Erhan, Z.N.; Beyazıt, A.; Pışkın, Ç.; Deniz, A.; et al. Seroprevalence of Babesia bovis and B. bigemina in cattle in Turkey. Pendik Vet. Mikrobiyol. Derg 2010, 37, 33-42.

111. Tanyüksel, M.; Vatansever, Z.; Karaer, Z.; Araz, E.; Haznedaroglu, T.; Yukari, B.A.; Acici, M. Sığır babesiosisinin epidemiyolojisi ve zoonotik önemi. Turkiye Parazitol. Derg. 2002, 26, $42-47$.

112. Yildirim, A.; Duzlu, O.; Inci, A.; Önder, Z.; Ciloglu, A. Sı̆̆ırlarda Babesia bovis ve Babesia bigemina'nın Reverse Line Blotting, Nested PCR ve Real Time PCR Teknikleri İle Karşılaştırmalı Tanısı. Kafkas Univ. Vet. Fak. Derg. 2013, 19, 895-902. [CrossRef]

113. Mimioğlu, M.G.K.; Sayın, F. Veteriner ve Tıbbi Protozooloji II; Ankara Üniversitesi Basımevi: Ankara, Turkey, 1969.

114. Vatansever, Z.; Ica, A.; Deniz, A.; Nalbantoğlu, S.; Karaer, Z.; Çakmak, A.; Sparagano, O. Ankara yöresinde sığırlarda kene kaynaklı protozoon enfeksiyonlarının yayılışının reverse line blotting (RLB)ve indirek floresan antikor testi (IFAT) ile saptanması. In Proceedings of the13th Ulusal Parazitoloji Kongresi, Konya, Turkey, 8-12 September 2003; p. 194.

115. Altay, K.; Aydin, M.F.; Dumanli, N.; Aktas, M. Molecular detection of Theileria and Babesia infections in cattle. Vet. Parasitol. 2008, 158, 295-301. [CrossRef] [PubMed]

116. Kose, O.B.H.B.; Bakirci, S.; Karagenc, T.; Aksulu, A.; Yukari, B.A.; Adanir, R.; Yildiz, S.; Eren, H. Research of Theileria and Babesia species in ruminantia of Burdur province by reverse line blot hybridisation technique. In Proceedings of the 20 Ulusal Parazitoloji Kongresi (Uluslararası Katılımlı), Eskisehir, Turkey, 25-29 September 2017.

117. Altay, K.; Atas, A.D.; Ograk, Y.Z.; Ozkan, E. Survey of Theileria, Babesia and Anaplasma infections of cattle and ticks from Sivas province of Turkey. Erciyes Üniv. Vet. Fak. Derg. 2020, 17, 32-38.

118. Yildirim, D. Önder; Sığırlarda Babesia bovis ve Babesia bigemina'nın Real-Time PCR ile araştırılması ve izolatların moleküler karakterizasyonu. Ankara Üniv. Vet. Fak. Derg. 2015, 62, 27-35. [CrossRef]

119. Inci, Ç.A. Babesia bigemina Kayseri/Türkiye suşunun in vivo ve in vitro izolatlarında apikal membran antijen-1 proteininin moleküler karakterizasyonu ve ekspresyonu. Ankara Üniv. Vet. Fak. Derg. 2018, 65, 239-246. [CrossRef]

120. Goksu, K. Ankara ve civarı sı̆̆ırlarında theileriosis üzerinde sistematik araştırmalar. Ankara Üniv. Vet. Fak. Derg. 1959, 115, 60.

121. Goksu, K. Yurdumuzun çeşitli bölgelerinde sı̆̆ırlarda Piroplasmida enfeksiyonları (piroplasmossis, babesiosis, theileriosis ve anaplasmosis'in yayılış durumları). Türk. Vet. Hek. Dern. Derg. 1970, 40, 29-39.

122. Tuzer, E. İstanbul ili ve çevresinde sığırlarda görülen Babesia, Theileria ve Anaplasma türleri ve bunlardan oluşan enfeksiyonların yayılışı üzerinde araştırma. İstanbul Üniv. Vet. Fak. Derg. 1981, 8, 97-110.

123. Ozer, E.; Erdogmus, S.Z.; Köroğlu, E.; Yilmaz, F. Malatya ve Güneydoğu Anadolu illerinde sığır, koyun ve keçilerde bulunan kan parazitleri ve yayılışları. Turk. J. Vet. Am. Sci. 1993, 17, 209-215.

124. Acici, M. Samsun ve yöresi sığırlarında kan parazitlerinin yayılışı. Etlik. Vet. Mik. Derg. 1995, 8, $271-277$.

125. Inci, A.; Cakmak, A.; Karaer, Z.; Dincer, S.; Sayin, F.; Ica, A. Seroprevalence of bovine babesiosis around Kayseri. Turk. J. Vet. Anim. Sci. 2002, 26, 1345-1350.

126. Inci, A. Ankara'nın Çubuk Ilçesinde Sı̆̆ırlarda Babesiosis'in Seroinsidensi Üzerine Araştırmalar. Ph.D. Thesis, Üniversitesi Sağlık Bilimleri Enstitüsü, Ankara, Turkey, 1992.

127. Sayın, F.; Friedhoff, K.T.; Dincer, S.; Karaer, Z.; Cakmak, A. Beytepe köyünde sığır babesiosisi üzerinde seroepidemiyolojik araştırmalar. In Proceedings of the 6th Ulusal Parazitoloji Kongresi, Istanbul, Turkey, 26-29 September 1989.

128. Eren, H. Ankara yöresinde sığır babesiosisinin sero-prevalansı. Ankara Üniv. Vet. Fak. Derg. 1993, 40, $23-27$.

129. Ica, A. Sığırlarda bazı Babesia türlerinin indirek floresan antikor ve reverse line blotting yöntemi ile karşılaştırmalı tanısı. Erciyes Üniv. Vet. Fak. Derg. 2004, 1, 77-85.

130. Aktas, M.; Dumanli, N.; Karaer, Z.; Cakmak, A.; Sevgili, M. Elazıg, Malatya, ve Tunceli illerinde sığırlarda Babesia türlerinin seroprevalans1. Turk. J. Vet. Anim. Sci. 2001, 25, 447-451.

131. Kalkan, K.; Ozcelik, S.; Malatyalı, E. Sivas'ta sıgırlarda babesiosis seroprevalansı. Turkiye Parazitol. Derg. 2010, 34, 11-16. 
132. Bilgin, Z. Trakya'da Sıgırlarda bulunan Theileria ve Babesia türlerinin ve bunların sıgırlarda yaygınlıının reverse line blooting (rlb) teknigi ile arastırılması. Ph.D. Thesis, Istanbul University, Istanbul, Turkey, 2007.

133. Duzlu, O.; Inci, A.; Yildirim, A. Karadeniz Bölgesi'ndeki sıgırlardan elde edilen Babesia bovis suslarının moleküler karakterizasyonu. ERÜ Să̆. Bil. Derg. 2011, 20, 18-28.

134. Yavuz, A.; Inci, A.; Duzlu, O.; Bişkin, Z.; Yildirim, A. Molecular Characterization of Babesia bovis msa-2c Gene. Turk. J. Parasitol. 2011, 35, 140-144. [CrossRef] [PubMed]

135. Mimioglu, M. Samsun, Ordu, Giresun ve Bolu Vilayetlerinde "Haematurai vesicalis bovis"li sığırlarda parasitolojik araştırmalar. Ankara Üniv. Vet. Fak. Derg. 1955, 11, 183-192.

136. Ozcan, C.H. Ankara ve civarında evcil hayvanlarda görülen Piroplasmose vakaları ve tedavileri üzerinde araştırmalar. A. Ü. Vet. Fak. Yay. 1961, 143.

137. Hoffmann, G.H.F.; Schein, E.; Gerber, H.G. Saisonales auftreten von zecken und piroplasmen bei haustieren in des asiatischen provinzen der Turkei. Berl. Münch Tierarztl. Wschr. 1971, 84, 152-156.

138. Dumanli, N.; Ozer, E. Elazı̆̆ yöresinde sığırlarda görülen kan parazitleri ve yayılışları üzerinde araştırmalar. Selçuk Üniv Vet. Fak. Derg. 1987, 3, 159-166.

139. Dincer, S.; Sayin, F.; Karaer, Z.; Cakmak, A.; Friedhoff, K.T.; Muller, I.; Inci, A.; Yukarı, B.A.; Eren, H. Karadeniz bölgesi sı̆̆ırlarında bulunan kan parazitlerinin sero-insidensi üzerine araştırmalar. Ankara Üniv. Vet. Fak. Derg. 1991, 38, 206-226.

140. Çakmak, A.; Öz, İ. Adana yöresi sığırlarında kan protozoonlarının serodiagnozu. Ankara Üniv. Vet. Fak. Derg. 1993, 40, 70-77.

141. Vatansever, Z.; Nalbantoglu, S.; Çakmak, A. Çukurova bölgesinde sı̆̆ır babesiosis'nin epidemiyolojisi. In Proceedings of the 12th Ulusal Parazitoloji Kongresi, Elazig, Turkey, 24-28 September 2001.

142. Sevinc, F.; Sevinc, M.; Birdane, F.M.; Altinoz, F. Prevalence of Babesia bigemina in cattle. Rev. Med. Vet. Toulouse 2001, 152, 395-398.

143. Kaya, G.; Cakmak, A.; Karaer, Z. Seroprevalance of theileriosis and babesiosis of cattle. Medycyna Wet. 2006, 62, 156-158.

144. Sevgili, M.; Cakmak, A.; Gokcen, A.; Altas, M.G.; Ergun, G. Prevalence of Theileria annulata and Babesia bigemina in Cattle in the Vicinity of Sanliurfa. J. Anim. Vet. Adv. 2010, 9, 292-296. [CrossRef]

145. Ica, A.; Inci, A.; Yildirim, A. Parasitological and molecular prevalence of bovine Theileria and Babesia species in the vicinity of Kayseri. Turk. J. Vet. Anim. Sci. 2007, 31, 33-38.

146. Zhou, M.; Cao, S.; Sevinc, F.; Sevinc, M.; Ceylan, O.; Moumouni, P.F.A.; Jirapattharasate, C.; Liu, M.; Wang, G.; Iguchi, A.; et al. Molecular detection and genetic identification of Babesia bigemina, Theileria annulata, Theileria orientalis and Anaplasma marginale in Turkey. Ticks Tick-Borne Dis. 2016, 7, 126-134. [CrossRef] [PubMed]

147. Walton, T.E. The impact of diseases on the importation of animals and animal products. Ann. N. Y. Acad. Sci. 2000, 916, 36-40. [CrossRef] [PubMed]

148. Barré, N.; Happold, J.; Delathière, J.-M.; Desoutter, D.; Saléry, M.; De Vos, A.; Marchal, C.; Perrot, R.; Grailles, M.; Mortelecque, A. A campaign to eradicate bovine babesiosis from New Caledonia. Ticks Tick-Borne Dis. 2011, 2, 55-61. [CrossRef] [PubMed]

149. Gebrekidan, H.; Nelson, L.; Smith, G.; Gasser, R.B.; Jabbar, A. An outbreak of oriental theileriosis in dairy cattle imported to Vietnam from Australia. Parasitology 2016, 144, 738-746. [CrossRef] [PubMed]

150. Madder, M.; Adehan, S.; De Deken, R.; Adehan, R.; Lokossou, R. New foci of Rhipicephalus microplus in West Africa. Exp. Appl. Acarol. 2012, 56, 385-390. [CrossRef] [PubMed]

151. Grisi, L.; Leite, R.C.; Martins, J.R.D.S.; De Barros, A.T.M.; Andreotti, R.; Cançado, P.H.D.; De León, A.A.P.; Pereira, J.B.; Villela, H.S. Reassessment of the potential economic impact of cattle parasites in Brazil. Rev. Brasil. Parasitol. Vet. 2014, 23, 150-156. [CrossRef]

152. Sivakumar, T.; Tuvshintulga, B.; Kothalawala, H.; Silva, S.S.P.; Lan, D.T.B.; Long, P.T.; Ybañez, A.P.; Ybañez, R.H.D.; Benitez, D.F.; Tayebwa, D.S.; et al. Host range and geographical distribution of Babesia sp. Mymensingh. Transbound. Emerg. Dis. 2020. [CrossRef]

153. Gulegen, E.; Giriskin, A.O.; Bakırcı, S.; Senlik, B.; Aydın, L. Sığırların doğal kene enfestasyonlarında bazı sentetik pyrethroid'lerin etkisi. Etlik. Vet. Mikrobiyol. Derg. 2011, 22, $27-31$.

154. Guven, E.; Deniz, A.; Gunduz, N.; Ozubek, S.; Kar, S.; Aktas, M.; Vatansever, Z. Kırım-Kongo Kanamalı Ateşi hastalığının endemik olduğu bir bölgede kene popülasyonunu kontrol amacıyla sığırlarda 1 Flumethrin uygulanmasının etkinliği. In Proceedings of the 18th Ulusal Parazitoloji Kongresi, Denizli, Turkey, 1-4 September 2013. 
155. Brayton, K.A.; Lau, A.O.T.; Herndon, D.R.; Hannick, L.; Kappmeyer, L.S.; Berens, S.J.; Bidwell, S.L.; Brown, W.C.; Crabtree, J.; Fadrosh, D.; et al. Genome Sequence of Babesia bovis and Comparative Analysis of Apicomplexan Hemoprotozoa. PLoS Pathog. 2007, 3, e148-13. [CrossRef]

156. Suarez, C.E.; Bishop, R.; Alzan, H.; Poole, W.; Cooke, B.M. Advances in the application of genetic manipulation methods to apicomplexan parasites. Int. J. Parasitol. 2017, 47, 701-710. [CrossRef] [PubMed]

157. Suarez, C.E.; Alzan, H.F.; Cooke, B.M. Genomics and Genetic Manipulation of Protozoan Parasites Affecting Farm Animals. In Parasitic Protozoa of Farm Animals and Pets; Springer Science and Business Media LLC: Berlin, Germany, 2018; pp. 413-438.

158. Vimonish, R.; Johnson, W.C.; Mousel, M.R.; Brayton, K.A.; Scoles, G.A.; Noh, S.M.; Ueti, M.W. Quantitative analysis of Anaplasma marginale acquisition and transmission by Dermacentor andersoni fed in vitro. Sci. Rep. 2020, 10, 470. [CrossRef] [PubMed]

159. Hakimi, H.; Ishizaki, T.; Kegawa, Y.; Kaneko, O.; Kawazu, S.-I.; Asada, M. Genome Editing of Babesia bovis Using the CRISPR/Cas9 System. mSphere 2019, 4, e00109-19. [CrossRef] [PubMed]

160. Contreras, M.; Kasaija, P.D.; Merino, O.; De La Cruz-Hernandez, N.I.; Gortazar, C.; De La Fuente, J. Oral Vaccination with a Formulation Combining Rhipicephalus microplus Subolesin with Heat Inactivated Mycobacterium bovis Reduces Tick Infestations in Cattle. Front. Cell. Infect. Microbiol. 2019, 9. [CrossRef] [PubMed]

161. De La Fuente, J.; Estrada-Peña, A. Why New Vaccines for the Control of Ectoparasite Vectors Have Not Been Registered and Commercialized? Vaccines 2019, 7, 75. [CrossRef] [PubMed]

Publisher's Note: MDPI stays neutral with regard to jurisdictional claims in published maps and institutional affiliations.

(C) 2020 by the authors. Licensee MDPI, Basel, Switzerland. This article is an open access article distributed under the terms and conditions of the Creative Commons Attribution (CC BY) license (http://creativecommons.org/licenses/by/4.0/). 